\title{
Monitoring of Juvenile Yearling Chinook Salmon and Steelhead Survival and Passage at Bonneville Dam, Spring 2010
}

Summary Report
GR Ploskey
DM Faber
MA Weiland
TJ Carlson

September 2012

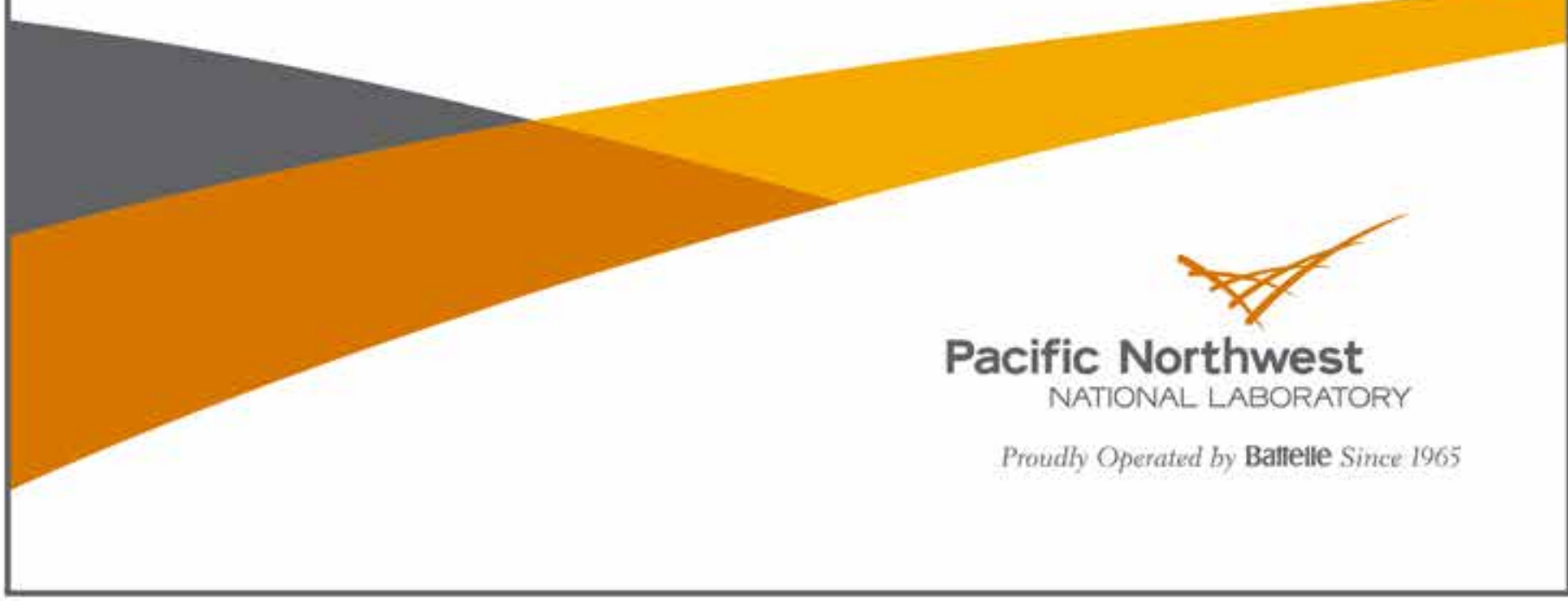




\title{
DISCLAIMER
}

This report was prepared as an account of work sponsored by an agency of the United States Government. Neither the United States Government nor any agency thereof, nor Battelle Memorial Institute, nor any of their employees, makes any warranty, express or implied, or assumes any legal liability or responsibility for the accuracy, completeness, or usefulness of any information, apparatus, product, or process disclosed, or represents that its use would not infringe privately owned rights. Reference herein to any specific commercial product, process, or service by trade name, trademark, manufacturer, or otherwise does not necessarily constitute or imply its endorsement, recommendation, or favoring by the United States Government or any agency thereof, or Battelle Memorial Institute. The views and opinions of authors expressed herein do not necessarily state or reflect those of the United States Government or any agency thereof.

\author{
PACIFIC NORTHWEST NATIONAL LABORATORY \\ operated by \\ BATTELLE \\ for the \\ UNITED STATES DEPARTMENT OF ENERGY \\ under Contract DE-AC05-76RL01830
}

Printed in the United States of America

$$
\begin{aligned}
& \text { Available to DOE and DOE contractors from the } \\
& \text { Office of Scientific and Technical Information, } \\
& \text { P.O. Box } 62 \text {, Oak Ridge, TN } 37831-0062 \text {; } \\
& \text { ph: }(865) 576-8401 \\
& \text { fax: (865) 576-5728 } \\
& \text { email: reports@adonis.osti.gov }
\end{aligned}
$$

Available to the public from the National Technical Information Service

5301 Shawnee Rd., Alexandria, VA 22312 ph: (800) 553-NTIS (6847)

email: orders@ntis.gov $<$ http://www.ntis.gov/about/form.aspx $>$ Online ordering: http://www.ntis.gov 


\section{Monitoring of Juvenile Yearling Chinook Salmon and Steelhead Survival and Passage at Bonneville Dam, Spring 2010}

Summary Report

GR Ploskey

DM Faber

MA Weiland

TJ Carlson

September 2012

Prepared for

U.S. Army Corps of Engineers, Portland District

Under a Government Order with the U.S. Department of Energy

Contract DE-AC05-76RLO 1830

Pacific Northwest National Laboratory

Richland, Washington 99352 



\section{Preface}

This study was conducted by the Pacific Northwest National Laboratory (PNNL) for the U.S. Army Corps of Engineers, Portland District (USACE). The PNNL project manager was Dr. Thomas J. Carlson. The USACE technical lead was Mr. Brad Eppard. The study was designed to estimate single-release survival and passage of fish passing Bonneville Dam and to provide additional performance measures at that site as stipulated in the Columbia Basin Fish Accords for yearling Chinook salmon and steelhead.

This report focuses on the spring run stocks, yearling Chinook salmon and steelhead. A separate report will present the findings of the survival studies of subyearling Chinook salmon smolts at Bonneville Dam during 2010. Comprehensive technical reports of the 2010 tagging studies at John Day, The Dalles, and Bonneville dams, including behavioral and fish passage results, will be delivered in spring 2011.

This report was originally published in February 2011. It was revised in August 2012, based on review comments from the Studies Review Work Group of these USACE's Anadromous Fish Evaluation Program. This August 2012 revision of the spring 2010 summary report for Bonneville Dam changed survival, efficiency, and travel time estimates to match estimates published in the final technical report. Survival estimates in the first summary report published in February 2011 were made using Atlas software that was designed to make tag-life corrections for a single-release survival model but not for a virtual single-release model (VSRM). In May 2011, Atlas software was updated to allow a virtual release of fish when the single-release model was used, and subsequent calculations of tag-life corrections for the VSRM were accurate for the final report. There also were sample size differences between the initial summary report and the final technical report that resulted in slight differences in metric estimates. Fish sampled in juvenile bypass systems were excluded from samples used to estimate metrics for the final report and for this revision of the summary report, but those fish were incorrectly included in earlier samples for initial summary report. This revision of the report also provides greater detail on the fate of fish collected for tagging, including the number and percent of collected fish that died before surgery or that were excluded from tagging for various reasons, tagged, or rejected from tagging because of maladies.

Suggested citation for this report:

Ploskey, GR, DM Faber, MA Weiland, and TJ Carlson. 2012. Monitoring of Juvenile Yearling Chinook Salmon and Steelhead Survival and Passage at Bonneville Dam, Spring 2010. PNNL-19898 Rev 1, summary report submitted to the U.S. Army Corps of Engineers, Portland District, Portland, Oregon, by Pacific Northwest National Laboratory, Richland, Washington. 



\section{Executive Summary}

The 2010 study documented in this report was conducted by researchers at the Pacific Northwest National Laboratory (PNNL) in collaboration with the Pacific States Marine Fisheries Commission (PSMFC), U.S. Army Corps of Engineers, Portland District (USACE), and the University of Washington (UW). The study was primarily designed to estimate survival rates of yearling Chinook salmon smolts and juvenile steelhead passing through (1) the Bonneville Dam forebay, (2) the forebay, dam, and $81 \mathrm{~km}$ of tailwater, and (3) through the dam and its various routes and $81 \mathrm{~km}$ of tailwater. The study also estimated additional passage performance measures, most of which were stipulated in the Columbia Basin Fish Accords.

The study was not an official compliance test as described by the 2008 Federal Columbia River Power System (FCRPS) Biological Opinion (BiOp) because passage conditions for the dam had not been finalized. The Powerhouse 1 (B1) sluiceway was expanded for 2010 to roughly triple the amount of flow passing through surface-flow outlets from the B1 forebay, but flow was not accurately measured in 2010 and some of the floating sluiceway gates were sticking during the fish passage season. Both conditions should be remedied for 2011. In addition, regional fishery managers wanted to add one more year of Powerhouse 2 (B2) behavioral guidance structure (BGS) evaluation and to evaluate the effects of two spill treatments on subyearling passage metrics and survival in summer. Unit 11, which is adjacent to the Bonneville Powerhouse 2 Corner Collector (B2CC) and critical for proper functioning of that surfaceflow outlet, was out of service throughout 2010. The USACE also wanted researchers to evaluate the performance of two independent cabled arrays deployed on every dam face (B1, the spillway, and B2) for detecting and tracking fish to make certain that the arrays would be ready for an official compliance test in 2011.

The primary purpose of this study was to estimate passage and route-specific survival rates for juvenile steelhead and yearling Chinook salmon smolts to a primary survival-detection array located $81 \mathrm{~km}$ downstream of the dam. The 2010 study also provided estimates of forebay residence time, tailrace egress time, spill passage efficiency (SPE), and spill + B2 Corner Collector (B2CC) passage efficiency, as required in the Columbia Basin Fish Accords. In addition, the study estimated forebay passage survival and survival of fish traveling from the forebay entrance array, through the dam and downstream through $81 \mathrm{~km}$ of tailwater. The Portland District had already decided to remove the BGS in the forebay of B2 after the 2010 because it was not highly effective at increasing B2CC passage efficiency in 2008 and 2009. Nevertheless, the presence of the BGS provided one last opportunity to see if it could increase B2CC passage efficiency over efficiencies observed in 2004 and 2005 before the BGS was installed.

Surviving acoustically tagged juvenile steelhead and yearling Chinook salmon smolts released in the Columbia River upstream of John Day Dam (near Arlington, Oregon), in The Dalles tailrace, and in the tailwater near Hood River, Oregon, were regrouped to form virtual releases either at the Bonneville Dam forebay entrance array or at the face of the dam. Single-release passage survival estimates were made for fish passing through three river reaches: 1) the dam and $81 \mathrm{~km}$ of tailwater; 2) the forebay, dam, and $81 \mathrm{~km}$ of tailwater; and 3) the forebay to the dam face. A total of 3880 yearling Chinook salmon smolts and 3885 juvenile steelhead were tagged and released to support survival studies at John Day Dam, The Dalles Dam, and Bonneville Dam in spring 2010. The Juvenile Salmon Acoustic Telemetry System (JSATS) tag model number ATS-156dB, weighing $0.438 \mathrm{~g}$ in air, was used in this investigation. 
This report provides a concise summary of spring 2010 results, except for most route-specific passage survival estimates, which will be provided in a comprehensive report in spring 2011. Dam passage survival to the Bonneville tailrace could not be estimated in 2010 because there were no reference releases of fish in the Bonneville tailrace or tailwater. Forebay to tailrace survival could not be estimated for the same reason.

The study results are summarized in the following tables.

Table ES.1. Estimates of Single-Release, Tag-Life-Corrected Estimates of Dam Passage Survival at Bonneville Dam in 2010

\begin{tabular}{|c|c|c|c|}
\hline Project & Year & Yearling Chinook Salmon & Steelhead \\
\hline Bonneville Dam & 2010 & $0.952\left(\partial_{E}=0.0040\right)$ & $0.945\left(\partial_{\mathrm{E}}=0.0043\right)$ \\
\hline \multicolumn{4}{|c|}{$\begin{array}{l}\text { Dam passage survival is defined by necessity as survival from the upstream face of the dam to the } \\
\text { primary array located } 81 \mathrm{~km} \text { downstream at river kilometer (rkm) } 153 \text {. Estimates are based on a } \\
\text { single-release model with tag-life corrections. SE = standard error }\end{array}$} \\
\hline
\end{tabular}

Table ES.2. Fish Accords Performance Measures at Bonneville Dam in 2010

\begin{tabular}{|c|c|c|}
\hline Performance Measures & Yearling Chinook Salmon & Steelhead \\
\hline Forebay Entrance Array to rkm 153 Survival & $0.951(\mathrm{SE}=0.0040)$ & $0.944(\mathrm{SE}=0.0043)$ \\
\hline $\begin{array}{l}\text { Forebay Residence Time (hours) } \\
\text { (Median; Mean) }\end{array}$ & $0.74 ; 1.27(\mathrm{SE}=0.046)$ & $1.69 ; 4.22(\mathrm{SE}=0.112)$ \\
\hline $\begin{array}{l}100 \text { m Forebay Residence Time (hours) } \\
\text { (Median; Mean) }\end{array}$ & $0.18 ; 1.84(\mathrm{SE}=0.267)$ & $1.43 ; 6.06(\mathrm{SE}=0.566)$ \\
\hline $\begin{array}{l}\text { Tailrace Egress Time (hours) } \\
\text { (Median; Mean) }\end{array}$ & $0.46 ; 0.94(\mathrm{SE}=0.104)$ & $0.41 ; 1.12(\mathrm{SE}=0.135)$ \\
\hline Project Passage Time & $1.29 ; 2.21(\mathrm{SE}=0.114)$ & $2.40 ; 5.32\left(\mathrm{~S}_{\mathrm{E}}=0.177\right)$ \\
\hline Spill Passage Efficiency (SPE) ${ }^{a}$ & $0.528(\mathrm{SE}=0.009)$ & $0.406(\mathrm{SE}=0.009)$ \\
\hline Spill + B2CC Passage Efficiency ${ }^{\text {b }}$ & $0.717(\mathrm{SE}=0.008)$ & $0.712\left(\mathrm{~S}_{\mathrm{E}}=0.008\right)$ \\
\hline
\end{tabular}


Table ES.3. Survival Study Summary

Year: 2010

Study Site(s): Bonneville Dam

Objective(s) of study: Estimate dam passage survival for yearling Chinook salmon and steelhead and associated Fish Accords performance measures using a single-release survival model; evaluate whether the behavioral guidance structure (BGS) in the B2 forebay improved B2CC passage efficiency.

Hypothesis (Null = H0; Alternative $=\mathrm{H} 1$ ):

H0: B2CC passage efficiency (2010 with B2 BGS) $\leq$ B2CC passage efficiency (2004 or 2005 without B2 BGS)

H1: B2CC passage efficiency (2010 with B2 BGS) >B2CC passage efficiency (2004 or 2005 without B2 BGS)

\begin{tabular}{|c|c|c|c|}
\hline \multicolumn{2}{|c|}{$\begin{array}{l}\text { Fish: Yearling Chinook salmon (CH1), steelhead (STH) } \\
\text { Source: John Day Dam fish collection facility }\end{array}$} & \multicolumn{2}{|l|}{$\begin{array}{l}\text { Implant Procedure: } \\
\text { Surgical: Yes; Injected: No }\end{array}$} \\
\hline Size (median): & STH & Sample Size: & STH \\
\hline Weight: & $78.1 \mathrm{~g}$ & \# release sites: & 3 \\
\hline $152.0 \mathrm{~mm}$ & $214.0 \mathrm{~mm}$ & \# releases & 94 \\
\hline & & Total \# released: & 3885 \\
\hline $\begin{array}{l}\text { Tag: } \\
\text { Type/model: Advanced Telemetry } \\
\text { Systems (ATS)-156dB } \\
\text { Weight (g): } 0.438 \text { g (air) }\end{array}$ & \begin{tabular}{|l|} 
Analytical Model: \\
Virtual/single release
\end{tabular} & $\begin{array}{l}\text { Characteristics of Estimate: } \\
\text { Effects Reflected (direct, total, etc): } \\
\text { Absolute or Relative: }\end{array}$ & $\begin{array}{l}\text { Direct } \\
\text { Relative }\end{array}$ \\
\hline
\end{tabular}

Environmental/Operating Conditions (daily from April 28 through June 18):

Discharge (kcfs): mean 246.4, minimum 153, maximum 391; No Treatments;

Temperature (deg C): mean 13.01, minimum 11.10, maximum 16.10

Total Dissolved Gas (tailrace): mean 112\%, minimum 106\%, maximum $116 \%$

Unique Study Characteristics: Turbine Unit 11 was offline all year; first year B1 sluiceway was widened for increased discharge; the B2 BGS was installed in the B2 forebay; turbine intake extensions were installed at every other intake on north half of B2 (15A, 15C, 16B, 17A, 17C, 18B).

Survival and Passage Estimates:

$$
\begin{array}{cc}
\text { Yearling Chinook } & \text { Steelhead } \\
0.951(\mathrm{~S}=0.0040) & 0.944(\mathrm{SE}=0.0043) \\
0.952(\mathrm{SE}=0.0040) & 0.945(\mathrm{SE}=0.0043) \\
0.74 ; 1.27(\mathrm{SE}=0.046) & 1.69 ; 4.22(\mathrm{SE}=0.112) \\
0.18 ; 1.84(\mathrm{SE}=0.267) & 1.43 ; 6.06(\mathrm{SE}=0.566) \\
0.46 ; 0.94(\mathrm{SE}=0.144) & 0.41 ; 1.12(\mathrm{SE}=0.135) \\
1.29 ; 2.21(\mathrm{SE}=0.114) & 2.40 ; 5.32(\mathrm{SE}=0.177) \\
0.528(\mathrm{SE}=0.009) & 0.406(\mathrm{~S} \mathrm{E}=0.009) \\
0.717(\mathrm{~S} \mathrm{E}=0.008) & 0.712(\mathrm{~S}=0.008)
\end{array}
$$$$
\text { Survival: Forebay entrance array (CR236) to CR153 }
$$$$
\text { Survival: Dam face to the primary array (CR153) }
$$$$
\text { Forebay Residence Time (hours) }
$$$$
\text { (median; mean) }
$$$$
\text { 100-m Forebay Residence Time (hours) }
$$$$
\text { (median; mean) }
$$$$
\text { Tailrace Egress Time (hours) }
$$$$
\text { (median; mean) }
$$$$
\text { Project Passage Time (CR236 to CR233) }
$$$$
\text { (median; mean) }
$$$$
\text { Spill passage efficiency }
$$$$
\text { Spill + B2CC passage efficiency }
$$

Results: This was not an official compliance test requiring paired reference releases, but single-release estimates for yearling Chinook salmon still exceeded the 2008 Biological Opinion (BiOp) requirement of 0.96, and single-release estimates for steelhead were very close to the BiOp requirement and may have met the requirement had there been reference releases to produce absolute survival estimates. Spill-passage efficiency was as high as or higher than previously reported based on previous radio telemetry and fixed aspect hydroacoustic studies. 



\section{Acknowledgments}

This study was the result of hard work by dedicated scientists (listed below) from the Pacific Northwest National Laboratory (PNNL), Pacific States Marine Fisheries Commission (PSMFC), U.S. Army Corps of Engineers, Portland District (USACE), and the University of Washington (UW). Their teamwork and attention to detail, schedule, and budget were essential for the study to succeed in providing high-quality, timely results to decision-makers.

- PNNL: C Arimescu, G Batten, B Bellgraph, R. Brown, S Carpenter, J Carter, K Carter, E Choi, Z Deng, K Deters, G Dirkes, E Fischer, T Fu, G Gaulke, K Hall, K Ham, R Harnish, M Hennen, J Hughes, M Hughes, G Johnson, F Khan, J Kim, K Knox, B Lamarche, K Lavender, J Martinez, G McMichael, B Noland, E Oldenburg, I Royer, N Tavan, S Titzler, N Trimble, C Woodley, and S Zimmerman.

- PSMFC: R Martinson, P Kahut, G Kolvachuk, C Anderson, A Cushing, D Etherington, G George, S Goss, T Monter, T Mitchell, R Plante, M Walker, R Wall, M Wilberding.

- USACE: B Eppard, D Schwartz, M Langeslay, and mechanics, operators, and biologists at the Bonneville Project (J Rerecich, B Hausmann, K Welch)

- UW: J Skalski, J Lady, A Seaburg, R Townsend, and P Westhagen. 



\section{Acronyms and Abbreviations}

\begin{tabular}{|c|c|}
\hline${ }^{\circ} \mathrm{C}$ & degree(s) Celsius \\
\hline $\mathrm{CHO}$ & subyearling Chinook salmon \\
\hline $\mathrm{CH} 1$ & yearling Chinook salmon \\
\hline $3 \mathrm{D}$ & three dimensional \\
\hline B1 & Bonneville Powerhouse 1 \\
\hline B2 & Bonneville Powerhouse 2 \\
\hline B2CC & Bonneville Powerhouse 2 Corner Collector \\
\hline $\mathrm{BiOp}$ & Biological Opinion \\
\hline BRZ & boat-restricted zone \\
\hline FCRPS & Federal Columbia River Power System \\
\hline FPC & Fish Passage Center \\
\hline g & $\operatorname{gram}(\mathrm{s})$ \\
\hline $\mathrm{h}$ & hour(s) \\
\hline JSATS & Juvenile Salmon Acoustic Telemetry System \\
\hline kcfs & thousand cubic feet per second \\
\hline $\mathrm{km}$ & kilometer(s) \\
\hline $\mathrm{L}$ & liter(s) \\
\hline $\mathrm{m}$ & meter(s) \\
\hline $\mathrm{mg}$ & milligram(s) \\
\hline $\mathrm{mm}$ & millimeter(s) \\
\hline MOA & Memorandum of Agreement \\
\hline PIT & passive integrated transponder \\
\hline PNNL & Pacific Northwest National Laboratory \\
\hline PRI & pulse repetition interval \\
\hline rkm & river kilometer(s) \\
\hline $\mathrm{RM}$ & river mile(s) \\
\hline RME & research, monitoring, and evaluation \\
\hline ROR & run-of-river \\
\hline RPA & Reasonable and Prudent Alternative \\
\hline SE & standard error \\
\hline SMF & Smolt Monitoring Facility \\
\hline SPE & spill passage efficiency \\
\hline STH & steelhead \\
\hline USACE & U.S. Army Corps of Engineers \\
\hline UW & University of Washington \\
\hline
\end{tabular}





\section{Contents}

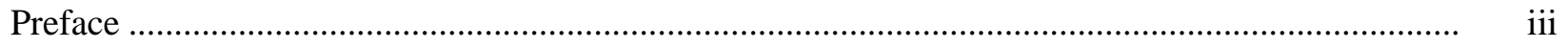

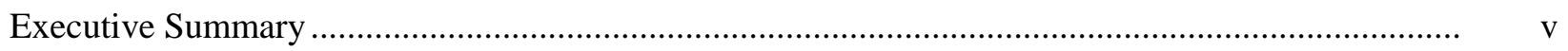

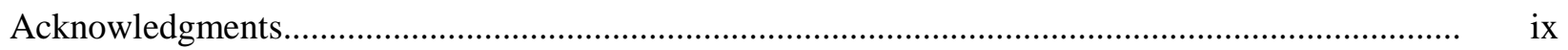

Acronyms and Abbreviations ..................................................................................................... xi

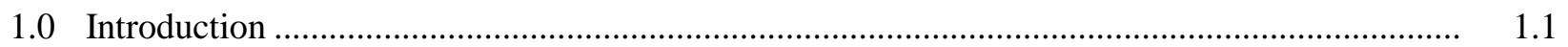

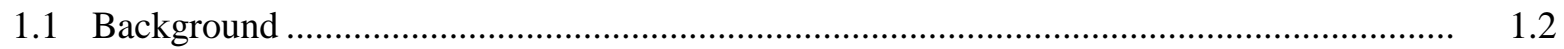

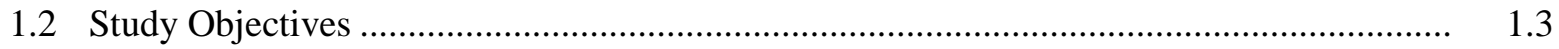

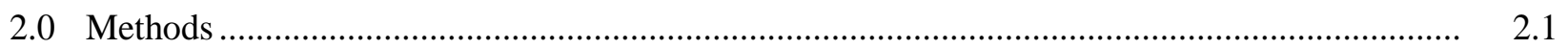

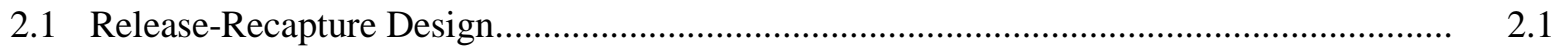

2.2 Handling, Tagging, and Release Procedures................................................................. 2.2

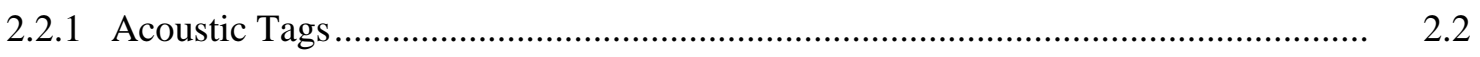

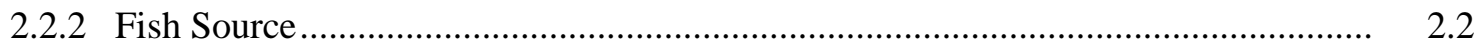

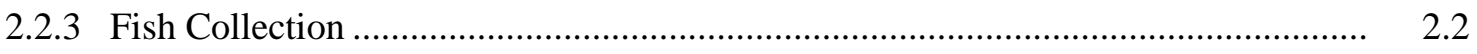

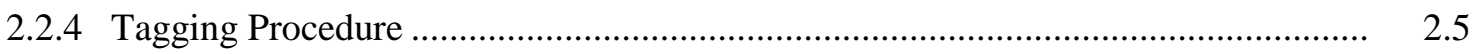

2.2.5 Release Procedures............................................................................................. 2.5

2.3 Acoustic Signal Processing ........................................................................................ 2.6

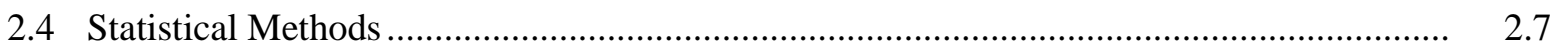

2.4.1 Estimation of Passage Survival ......................................................................... 2.7

2.4.2 Tag-Life Analysis........................................................................................... 2.8

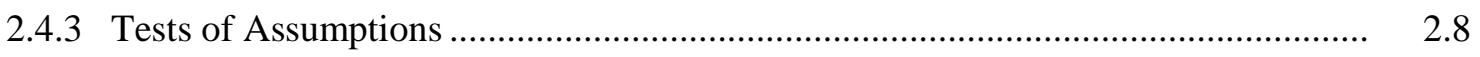

2.4.4 Estimation of Travel Times ................................................................................ 2.9

2.4.5 Estimation of B2CC Passage Efficiency ............................................................... 2.9

2.4.6 Estimation of Spill Passage Efficiency …............................................................ 2.10

2.4.7 Estimation of Spill + B2CC Passage Efficiency ................................................. 2.10

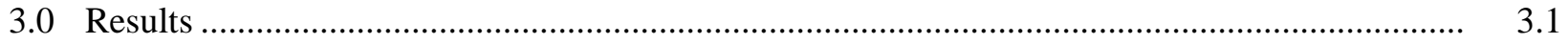

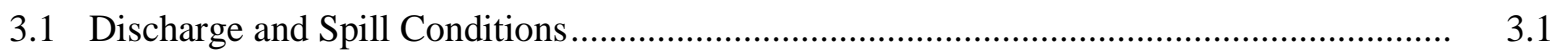

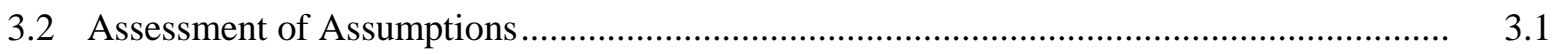

3.2.1 Fish Size Distribution..................................................................................... 3.2

3.2.2 Tag-Life Corrections ................................................................................... 3.2

3.2.3 Handling Mortality and Tag Shedding ................................................................. 3.3

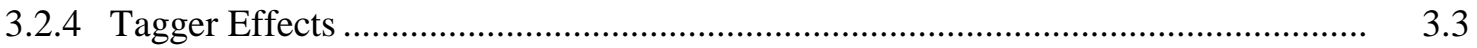

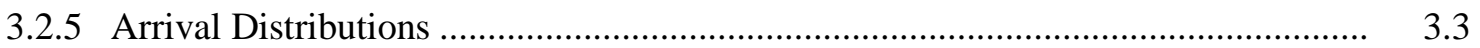

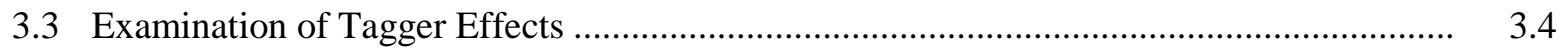

3.4 Estimates of Reach Survival and Release-Specific Survival ............................................ 3.5

3.4.1 Yearling Chinook Salmon ................................................................................... 3.5

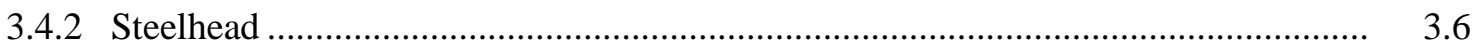

3.5 Forebay Residence Time .................................................................................................. 
3.6 100-m Forebay Residence Time..............................................................................

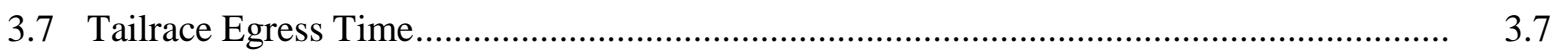

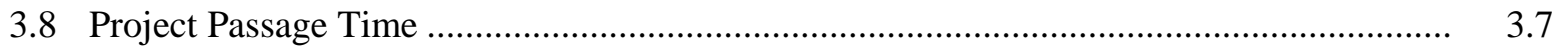

3.9 Estimates of Spill Passage Efficiency …..................................................................... 3.7

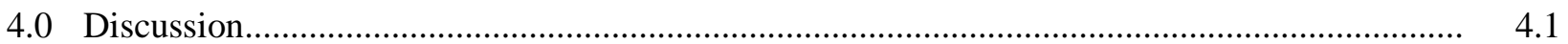

4.1 Reasonableness of Model Assumptions ..........................................................................

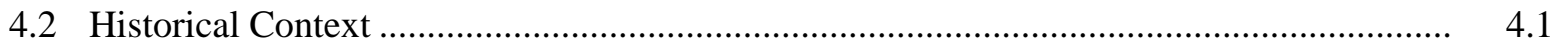

4.3 Statistical Performance........................................................................................ 4.2

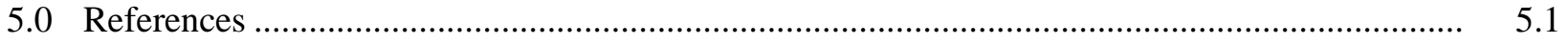

Appendix A - Capture Histories, Tag-Life-Corrected Survival Estimates, and Capture

Probabilities

\section{Figures}

2.1 Schematic of the 2010 Study Design Showing the Three Releases of Fish that Could Be Regrouped to Form Virtual Releases at the Forebay Entrance Array or Dam-Face Array and Subsequent Detections or Non-Detections on Three Downstream Arrays that Were Used to Create Capture Histories for Estimating Single-Release Survival Rates Down to the Primary Array

3.1 Daily Outflow and Spill Discharge of Water from Bonneville Dam for the Period from April 26 Through June 13, 2010 and 10-year Averages from 2000 Through 2009..

3.2 Comparison of Length Frequency Distributions of Tagged and Untagged Fish Passing the John Day Dam Smolt Monitoring Facility....

3.3 Individual Failure Times for the $n=49$ Acoustic Tags Used in the Tag-Life Study, Along with the Fitted 4-Parameter Vitality Model of Li and Anderson

3.4 Cumulative Time of Arrival of Tagged Juvenile Steelheads Regrouped at the Bonneville Dam Faces to Form a Virtual Dam-Passage Release at All Downstream Detection Sites Versus Tag-Life Curve

3.5 Cumulative Time of Arrival of Tagged Yearling Chinook Salmon Smolts Regrouped at the Bonneville Dam Faces to Form a Virtual Dam-Passage Release at All Downstream Detection Sites Versus Tag-Life Curve

3.6 Plot Comparing Virtual-Release Dam-Passage Survival Estimates Among the Three Releases of Fish Upstream of Bonneville Dam in 2010 


\section{Tables}

ES.1Estimates of Single-Release, Tag-Life-Corrected Estimates of Dam Passage Survival at

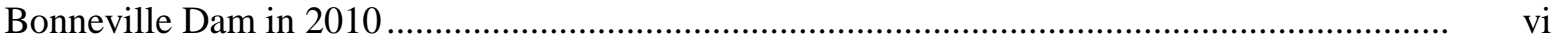

ES.2 Fish Accords Performance Measures at Bonneville Dam in 2010 ............................................. vi

ES.3Survival Study Summary ................................................................................................. vii

2.1 Sample Sizes of Acoustically Tagged Yearling Chinook Salmon and Steelhead Releases

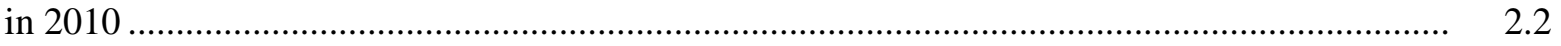

2.2 Summary of the Number and Percent of Fish that Were Rejected, Excluded, Tagged and Released Alive, Tagged and Released Dead, or Exceeded the Daily Tagging Quota in 2010

2.3 Number and Percent Rejected Because of Maladies

2.4 Number and Percent Excluded from Tagging for Other Reasons.

2.5 Relative Release Times for the Acoustic-Tagged Fish to Accommodate Downstream Mixing.

4.1 Comparison of Paired-Release Passage Survival Estimates for 2004, 2005, 2008, 2009, and 2010 



\subsection{Introduction}

In 2010, researchers at the Pacific Northwest National Laboratory (PNNL) in collaboration with the Pacific States Marine Fisheries Commission (PSMFC), U.S. Army Corps of Engineers, Portland District (USACE), and the University of Washington (UW), conducted this juvenile fish passage and survival study. The study was primarily designed to estimate the survival of yearling Chinook salmon and juvenile steelhead passing through two river reaches around Bonneville Dam 1) the forebay, dam, and $81 \mathrm{~km}$ of tailwater, and 2) just the dam and various routes through the dam and $81 \mathrm{~km}$ of tailwater. Additional passage performance measures were estimated, most of which were stipulated in the Columbia Basin Fish Accords.

The 2010 study was not an official compliance test as described by the 2008 Federal Columbia River Power System (FCRPS) Biological Opinion (BiOp; NOAA 2008), because passage conditions for the dam had not been finalized. The Powerhouse 1 (B1) sluiceway was expanded for 2010 to roughly triple the amount of flow passing through surface flow outlets from the B1 forebay, but flow was not accurately measured in 2010 and some of the floating sluiceway gates were sticking during the fish passage season. Both of these conditions should be remedied for 2011. In addition, regional fishery managers wanted to add one more year of Powerhouse 2 (B2) behavioral guidance structure (BGS) evaluation and for summer 2010 wanted to evaluate effects of two spill treatments on fish-passage metrics and survival. Unit 11, which is adjacent to the Bonneville Powerhouse 2 Corner Collector (B2CC) and critical for proper functioning of that surface-flow outlet, was out of service throughout 2010. The USACE also wanted researchers to evaluate the performance of two independent cabled arrays deployed on every dam face (B1, the spillway, and B2) for detecting and tracking fish to make certain that the arrays would be ready for an official compliance test in 2011.

The purpose of this study was to estimate dam passage and route specific survival rates for juvenile steelhead and yearling Chinook salmon smolts to a primary survival-detection array located $81 \mathrm{~km}$ downstream of the dam and to evaluate a BGS in the B2 forebay. The 2010 study also provided estimates of forebay residence time, tailrace egress time, spill passage efficiency (SPE), and spill + B2CC passage efficiency, as required in the Columbia Basin Fish Accords. In addition, the study estimated forebay passage survival and survival of fish traveling from the forebay entrance array, through the dam and downstream through $81 \mathrm{~km}$ of tailwater.

Surviving acoustically tagged juvenile steelhead and yearling Chinook salmon smolts released in the Columbia River upstream of John Day Dam (near Arlington, Oregon), in The Dalles tailrace, and in the tailwater near Hood River, Oregon, were available to form virtual releases either at the Bonneville Dam forebay entrance array or at the face of the dam. Single-release passage survival estimates were made for fish passing through two river reaches: 1) the dam and $81 \mathrm{~km}$ of tailwater and 2) the forebay, dam, and $81 \mathrm{~km}$ of tailwater. A total of 3880 yearling Chinook salmon smolts and 3885 juvenile steelhead were tagged and released to support survival studies at John Day Dam, The Dalles Dam, and Bonneville Dam in spring 2010. The Juvenile Salmon Acoustic Telemetry System (JSATS) tag model number ATS-156dB, weighing $0.438 \mathrm{~g}$ in air, was used in this investigation. 


\subsection{Background}

The 2008 BiOp on operation of the FCRPS contains a Reasonable and Prudent Alternative (RPA) that includes actions calling for measurements of juvenile salmonid survival (RPAs 52.1 and 58.1). These RPAs are being addressed as part of the federal research, monitoring, and evaluation (RME) effort for the FCRPS BiOp. Most importantly, the FCRPS BiOp includes performance standards for juvenile salmonid survival in the FCRPS against which the Action Agencies (Bonneville Power Administration, Bureau of Reclamation, and USACE) must compare its performance estimates, as follows (after the RME Strategy 2 of the RPA):

Juvenile Dam Passage Performance Standards - The Action Agencies juvenile performance standards are an average across Snake River and lower Columbia River dams of 96\% average dam passage survival for spring Chinook salmon and steelhead and 93\% average across all dams for Snake River subyearling Chinook. Dam passage survival is defined as survival from the upstream face of the dam to a standardized reference point in the tailrace.

The 2008 Columbia Basin Fish Accords Memorandum of Agreement [MOA] between the Three Treaty Tribes and FCRPS Action Agencies (3 Treaty Tribes and Action Agencies 2008), known informally as the Fish Accords ${ }^{1}$, contains three additional requirements relevant to the 2010 survival studies (after the MOA Attachment A):

Dam Survival Performance Standard - Meet the 96\% dam passage survival standard for yearling Chinook salmon and steelhead and the 93\% standard for subyearling Chinook. Achievement of the standard is based on 2 years of empirical survival data....

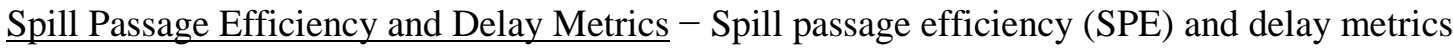
under current spill conditions . . . are not expected to be degraded ("no backsliding”) with installation of new fish passage facilities at the dams....

Future Research, Monitoring and Evaluation - The Action Agencies' dam survival studies for purposes of determining juvenile dam passage performance will also collect information about SPE, survival and delay between boat-restricted zones (BRZs), and other distribution and survival information. SPE and delay metrics will be considered in the performance check-ins or with Configuration and Operations Plan updates, but not as principal or priority metrics over dam survival performance standards. Once a dam meets the survival performance standard, SPE and delay metrics may be monitored coincidentally with dam survival testing.

This report summarizes the results of the 2010 spring acoustic-telemetry study of yearling Chinook salmon and steelhead at Bonneville Dam. This study is a precursor to a full-scale compliance study to be performed in 2011. Only single-release survival estimates were calculated for Bonneville Dam because there were no paired reference releases of fish downstream of Bonneville Dam in 2010. Therefore BiOp performance standards were not explicitly tested.

\footnotetext{
${ }^{1}$ Available at http://www.salmonrecovery.gov/Files/BiologicalOpinions/MOA_ROD.pdf
} 


\subsection{Study Objectives}

The purpose of spring 2010 monitoring at Bonneville Dam was to estimate performance measures outlined in the 2008 FCRPS BiOp and the Fish Accords for yearling Chinook salmon and juvenile steelhead using a single-release passage and survival model, evaluate B2 BGS performance, and evaluate the effects of two spill treatments in summer.

The purpose of spring 2010 monitoring at Bonneville Dam was to estimate single-release survival rates for yearling Chinook salmon and steelhead smolts, evaluate B2 BGS performance, and evaluate fishpassage metrics specified by the 2008 Fish Accords by taking advantage of fish released for the BiOp performance testing at The Dalles Dam. For each fish stock, the following metrics were estimated using the JSATS technology:

- In this report, dam passage survival is defined as survival from the upstream face of the dam to the first survival array located $81 \mathrm{~km}$ downstream of Bonneville Dam. The survival estimate includes the mortality of fish in this $81 \mathrm{~km}$ river reach in addition to mortalities associated with dam passage. A single-release point estimate $>96 \%$ also would exceed the BiOp standard for a paired-release estimate, because the single-release estimate is more conservative than the paired-release estimate.

- In this report, we present two estimates of fish-passage efficiency: 1) SPE, which is defined as the number of fish passing through the spillway divided by the number passing the dam, and 2) spill + B2CC passage efficiency, as specified in the 2008 Fish Accords.

- Forebay residence time, defined by the median, mean, and standard error of the mean times that smolts take to travel the last 100-m upstream of the dam before passing into the dam (i.e., from the 100 -m mark to the dam face).

- Tailrace egress time, defined as the median, mean, and standard error of the mean times that smolts take to travel through the dam to the downstream tailrace boundary.

- Project passage time, defined as the median, mean, and standard error of the mean times that smolts take to travel from the forebay entrance array through the dam to the tailrace egress array.

- Survival from the forebay entrance array to the primary array $81 \mathrm{~km}$ downstream of the dam was estimated instead of forebay-to-tailrace survival, which was specified as BRZ-to-BRZ survival in the Fish Accords. Forebay to tailrace survival estimates require tailrace and tailwater references releases that were not part of the 2010 study. We did provide a single-release estimate of survival from the forebay entrance array to the dam-face.

This report is designed to provide a succinct and timely summary of spring 2010 results, except for route-specific passage survival estimates, which will be provided in a comprehensive report in spring 2011. Dam passage survival to the Bonneville tailrace could not be estimated in 2010 because there were no reference releases of fish in the Bonneville tailrace or tailwater. Forebay to tailrace survival could not be estimated for the same reason. Therefore BiOp performance standards were not explicitly tested. Results are reported for the two fish stocks by survival measure and metric.

The study methods and results described in the ensuing sections of this report are reported by performance measure. 



\subsection{Methods}

Study methods involved fish release and recapture; the associated fish-handling, tagging, and release procedures; acoustic signal processing; and statistical and analytical approaches.

\subsection{Release-Recapture Design}

The release-recapture design used to estimate dam passage survival at Bonneville Dam consisted of a combination of a virtual release of fish at the forebay entrance array or at the face of the dam and the detection of the same fish below the dam (Figure 2.1). Releases of tagged fish near Arlington, Oregon, The Dalles tailrace, and Hood River, Oregon supplied a source of fish known to have arrived alive at the forebay entrance array or at the face of Bonneville Dam. By releasing the fish far enough upstream, they should have arrived at the dam in a spatial pattern typical of run-of-river (ROR) fish. This virtual-release group was then used to estimate survival through the dam and to $81 \mathrm{~km}$ downstream of the dam. We were unable to account and adjust for this extra mortality in the tailwater because there were no paired releases of fish below Bonneville Dam. We were unable to estimate forebay to tailrace survival rates for the same reason. The sizes of the releases of the acoustic-tagged fish used in the dam passage survival estimates are summarized in Table 2.1.

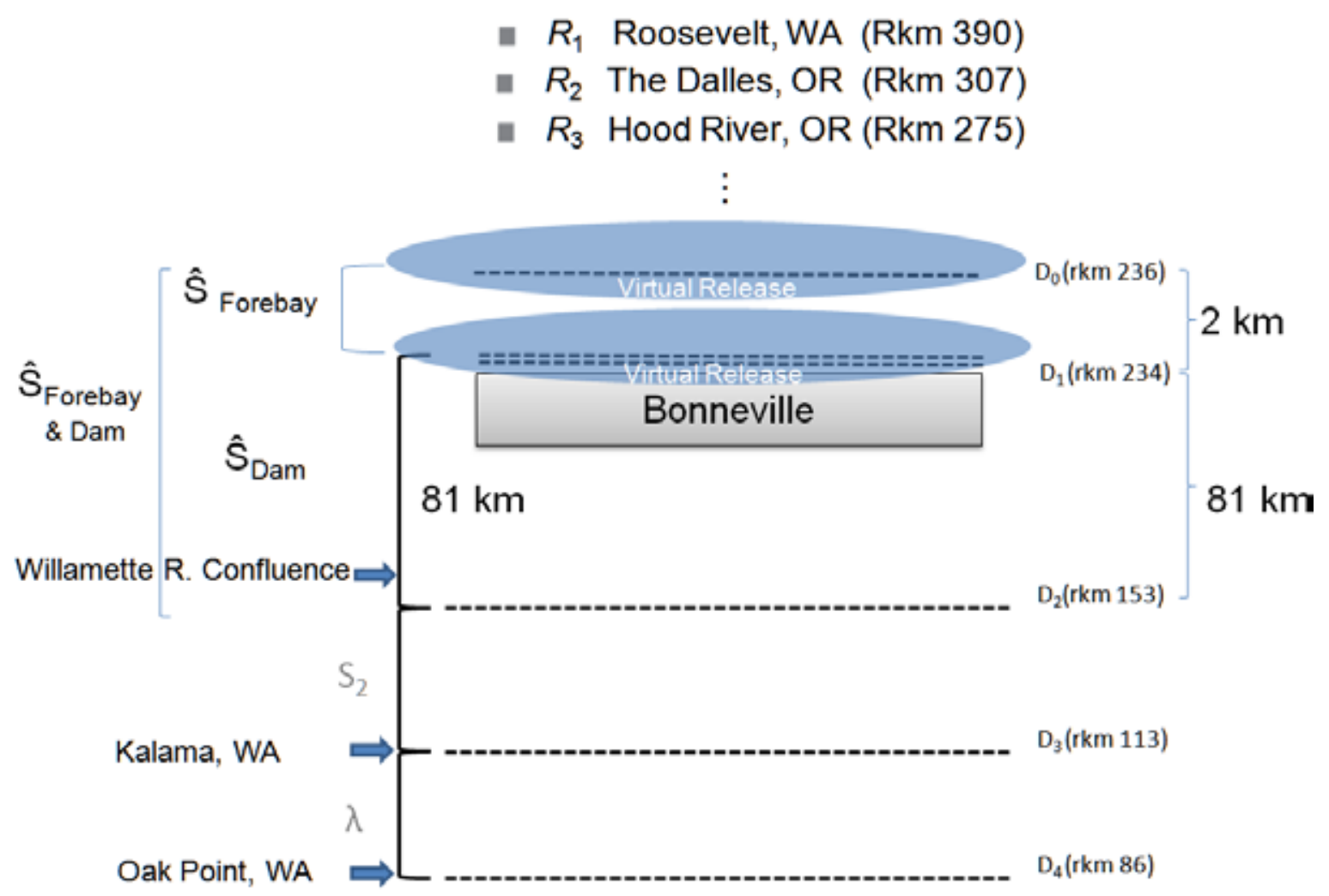

Figure 2.1. Schematic of the 2010 Study Design Showing the Three Releases of Fish that Could Be Regrouped to Form Virtual Releases at the Forebay Entrance Array $\left(D_{0}\right)$ or Dam-Face Array $\left(D_{1}\right)$ and Subsequent Detections or Non-Detections on Three Downstream Arrays (D2-D4) that Were Used to Create Capture Histories for Estimating Single-Release Survival Rates Down to the Primary Array (D2). 
Table 2.1. Sample Sizes of Acoustically Tagged Yearling Chinook Salmon and Steelhead Releases in 2010

\begin{tabular}{lcc}
\hline \multicolumn{1}{c}{ Release Location } & Yearling Chinook Salmon & Juvenile Steelhead \\
\hline Above John Day & 2287 & 2288 \\
The Dalles Dam Tailrace & 796 & 799 \\
Bonneville Reservoir & 797 & 798 \\
\hline
\end{tabular}

The three-dimensional (3D) double-detection array at the face of Bonneville Dam used to construct the virtual-release group was also used to identify the passage routes of fish through the dam. These passage-route data were used to calculate SPE and spill + B2CC passage efficiency. The 3D tracking data were further used to estimate forebay residence time within the $100-\mathrm{m}$ zone nearest the dam. The fish used in the virtual release at the face of the dam were used to estimate tailrace egress time.

A total of 49 acoustic tags were randomly sampled from the tags used in the spring season for a tag-life assessment. The tags were activated, held in river water, and monitored continuously until they failed. The information derived from the tag-life study was used to adjust the perceived survival estimates from the Cormack-Jolly-Seber release-recapture model according to the methods of Townsend et al. (2006).

\subsection{Handling, Tagging, and Release Procedures}

Fish obtained from the John Day Dam juvenile bypass system were surgically implanted with JSATS tags, and then transported to three different release points, as described in the following sections.

\subsubsection{Acoustic Tags}

The acoustic tags used in the spring 2010 study were manufactured by Advanced Telemetry Systems. Each tag, model number ATS-156dB, measured $12.02 \mathrm{~mm}$ in length, $5.21 \mathrm{~mm}$ in width, $3.72 \mathrm{~mm}$ in thickness, and weighed $0.438 \mathrm{~g}$ in air. The tags had a nominal transmission rate of 1 pulse every 3 seconds. Nominal tag life was expected to be about 23 days.

\subsubsection{Fish Source}

The yearling Chinook salmon and juvenile steelhead used in the study were all obtained from the John Day Dam juvenile bypass system. The Pacific States Marine Fisheries Commission diverted fish from the juvenile bypass system into an examination trough, as described by Martinson et al. (2006). Fish $\geq 95 \mathrm{~mm}$ in length without malformations or excessive descaling ( $>20 \%)$ were selected for tagging.

\subsubsection{Fish Collection}

Juvenile salmonids were diverted from the juvenile bypass system and then routed into a 1795-gal holding tank in the Smolt Monitoring Facility (SMF). About 150-200 smolts and other fishes were crowded with a panel net into a 20 - by 24-in. pre-anesthetic chamber. The water level in the chamber was lowered to about $8 \mathrm{in}$. (48 L) at which point fish were anesthetized with $60 \mathrm{~mL}$ of a stock tricaine methanesulfonate (MS-222) solution prepared at a concentration of $50 \mathrm{~g} / \mathrm{L}$. Once they were anesthetized, 
the fish were routed into the examination trough. Technicians added MS-222 as needed to maintain sedation, and 5 to $10 \mathrm{~mL}$ of PolyAquaTM to reduce fish stress. Water temperatures were monitored in the main holding tank and in the examination trough, and water in the trough was refreshed before temperatures there increased more than $2^{\circ} \mathrm{C}$ above those observed in the main holding tank.

Once fish were in the examination trough, smolts targeted for surgical procedures were evaluated in accordance with the following criteria:

- Qualifying (Acceptable) Conditions

- $\quad$ size $\geq 95 \mathrm{~mm}$

- visible elastomer tag(s) present or absent

- adipose-fin clipped or unclipped

- presence of trematodes, copepods, leeches

- short operculum

- healed (moderate) injuries (e.g., bird strikes)

- $\quad \leq 3 \%$ fungal patch

- minor fin blood

- partial descaling (3-19\%)

- steelhead (STH) with eroded pectoral or ventral fins (likely hatchery STH).

- Disqualifying Conditions

- $\quad \geq 20 \%$ descaling

- body punctures (showing blood; e.g., predator marks, bird strikes, head wounds, nose/snout injuries)

- obvious signs of bacterial kidney disease

- eye hemorrhage or pop eye

- $\quad>3 \%$ coverage with fungus

- deformed or emaciated

- holdovers (fish not "spring” yearling Chinook salmon [CH1] or "summer" subyearling Chinook salmon [CHO])

- passive integrated transponder (PIT)- or radio-tagged or other post-surgical fishes

- notable operculum damage (except short operculum)

- presence of columnaris, furuncles

- injured caudal peduncles

- injured caudal fins

- fin hemorrhage. 
We summarized the number and percent of fish collected for tagging according to their fate (Table 2.2). Excluded fish were released to the river through the SMF holding system after a 30-minute recovery period. Accepted fish were counted and moved in approximately equal proportions to six 80-gal pre-surgery holding tanks, where they were held for 18 to 30 hours before surgery. The pre-surgery holding duration depended on the time of collection and the time of tagging on the next day. Fish that were rejected during the tagging process were placed in a recovery tank to allow the anesthesia to wear off and then they were released back to the river through the bypass system. Most fish were tagged and released alive. We also tallied the number and percent of fish rejected from tagging because of maladies (Table 2.3) and excluded for other reasons (Table 2.4).

Table 2.2. Summary of the Number and Percent of Fish that Were Rejected, Excluded, Tagged and Released Alive, Tagged and Released Dead, or Exceeded the Daily Tagging Quota in 2010

\begin{tabular}{lrrrrrrr}
\hline \multicolumn{1}{c}{ Fate } & \multicolumn{2}{c}{ CH1 } & \multicolumn{2}{c}{ STH } & Total \\
\multicolumn{1}{c}{ Statistics } & \multicolumn{1}{c}{$\mathrm{n}$} & \multicolumn{1}{c}{$\%$} & \multicolumn{1}{c}{$\mathrm{n}$} & \multicolumn{1}{c}{$\%$} & \multicolumn{1}{c}{$\mathrm{n}$} & \multicolumn{1}{c}{$\%$} \\
\hline Rejected $^{(\mathrm{a})}$ & 297 & 6.5 & 427 & 8.9 & 724 & 7.7 \\
Excluded $^{(\mathrm{b})}$ & 209 & 4.5 & 309 & 6.4 & 518 & 5.5 \\
Tagged and Released Live $^{\text {Tagged and Released Dead }}{ }^{(\mathrm{c})}$ & 3880 & 84.3 & 3885 & 80.9 & 7765 & 82.6 \\
Extra Fish $^{(\mathrm{d})}$ & 33 & 0.7 & 37 & 0.8 & 70 & 0.7 \\
\hline Collected & 182 & 4.0 & 147 & 3.1 & 329 & 3.5 \\
\hline
\end{tabular}

(a) Because of maladies.

(b) Too short, too long, previously tagged, dead, wrong species, dropped, or jumped.

(c) Beyond overnight mortalities, others were sacrificed.

(d) Collected but not evaluated before the tagging quota was met.

Table 2.3. Number and Percent Rejected Because of Maladies

\begin{tabular}{lrrrrrr}
\hline \multicolumn{1}{c}{ Malady Description } & \multicolumn{2}{c}{ CH1 } & \multicolumn{2}{c}{ STH } & \multicolumn{2}{c}{ Total } \\
\hline & \multicolumn{1}{c}{$\mathrm{n}$} & \multicolumn{1}{c}{$\%$} & \multicolumn{1}{c}{$\mathrm{n}$} & \multicolumn{1}{c}{$\%$} & $\mathrm{n}$ & \multicolumn{1}{c}{$\%$} \\
\cline { 2 - 7 } BKD & 2 & 0.7 & 0 & 0.0 & 2 & 0.3 \\
Descaling $(\geq 20 \%)$ & 148 & 49.8 & 212 & 49.6 & 360 & 49.7 \\
Emaciated & 1 & 0.3 & 0 & 0.0 & 1 & 0.1 \\
Exophthalmia & 16 & 5.4 & 5 & 1.2 & 21 & 2.9 \\
Fin Rot & 5 & 1.7 & 1 & 0.2 & 6 & 0.8 \\
Fungus & 49 & 16.5 & 60 & 14.1 & 109 & 15.1 \\
Hemorrhaging & 9 & 3.0 & 2 & 0.5 & 11 & 1.5 \\
Lacerations & 25 & 8.4 & 50 & 11.7 & 75 & 10.4 \\
Lesions & 12 & 4.0 & 22 & 5.2 & 34 & 4.7 \\
Operculum Damage & 13 & 4.4 & 41 & 9.6 & 54 & 7.5 \\
Other & 8 & 2.7 & 23 & 5.4 & 31 & 4.3 \\
Parasites & 0 & 0.0 & 4 & 0.9 & 4 & 0.6 \\
Skeletal Deformities & 9 & 3.0 & 7 & 1.6 & 16 & 2.2 \\
\hline Total & 297 & 100.0 & 427 & 100.0 & 724 & 100.0 \\
\hline
\end{tabular}


Table 2.4. Number and Percent Excluded from Tagging for Other Reasons

\begin{tabular}{lrrrrrrr}
\hline & \multicolumn{2}{c}{ CH1 } & \multicolumn{2}{c}{ STH } & \multicolumn{2}{c}{ Total } \\
\multicolumn{1}{c}{ Reason for Exclusion } & $\mathrm{n}$ & \multicolumn{1}{c}{$\%$} & \multicolumn{1}{c}{$\mathrm{n}$} & \multicolumn{1}{c}{$\%$} & \multicolumn{1}{c}{$\mathrm{n}$} & \multicolumn{1}{c}{$\%$} \\
\hline Moribund & 0 & 0.0 & 0 & 0.0 & 0 & 0.0 \\
Previously tagged & 168 & 80.4 & 156 & 50.5 & 324 & 62.5 \\
$<$ 95 or $>$ 260 mm & 1 & 0.5 & 150 & 48.5 & 151 & 29.2 \\
Wrong species & 40 & 19.1 & 3 & 1.0 & 43 & 8.3 \\
Dropped/Jumped & 0 & 0.0 & 0 & 0.0 & 0 & 0.0 \\
\hline Total & 209 & 100.0 & 309 & 100.0 & 518 & 100.0 \\
\hline
\end{tabular}

\subsubsection{Tagging Procedure}

The fish to be tagged were anesthetized in an 18.9-L "knockdown" bucket with fresh river water and MS-222 (tricaine methanesulfonate; 80 to $100 \mathrm{mg} / \mathrm{L}$ ). Anesthesia buckets were refreshed repeatedly to maintain the temperature within $\pm 2{ }^{\circ} \mathrm{C}$ of current river temperatures. Each fish was weighed and measured before tagging.

During surgery, each fish was placed ventral side up and a gravity-fed anesthesia supply line was placed into its mouth. The dilution of the "maintenance" anesthesia was $40 \mathrm{mg} / \mathrm{L}$. Using a surgical blade, a 6- to 8-mm incision was made in the body cavity between the pelvic girdle and pectoral fin. A (PIT tag was inserted followed by an acoustic tag. Both tags were inserted toward the anterior end of the fish. The incision was closed using 5-0 Monocryl suture.

After closing the incision, the fish were placed in a dark 18.9-L transport bucket filled with aerated river water. Fish were held in these buckets for 18 to $24 \mathrm{~h}$ before being transported for release into the river. The loading rate was five fish per bucket.

\subsubsection{Release Procedures}

All fish were tagged at John Day Dam and transported by truck to release locations. Transportation routes were adjusted to provide equal travel times to each release location from John Day Dam. Upon arriving at a release site, fish buckets were transferred to a boat for transport to the in-river release locations. At each release transect, the fish were released at five specific locations across the breadth of the river channel. The purpose of this release strategy was to distribute fish in a way that better represents the actual spatial distribution of ROR fish.

Releases occurred for 37 consecutive days (from April 28 to June 1, 2010). Releases alternated between daytime and nighttime, every other day, over the course of the study. The timing of the releases at the three locations was staggered to help facilitate downstream mixing (Table 2.5). 
Table 2.5. Relative Release Times for the Acoustic-Tagged Fish to Accommodate Downstream Mixing. Releases were timed to accommodate approximately 60-h travel time between $R_{1}$ and $R_{3}$ and 15-h travel time between $R_{1}$ and $R_{2}$.

\begin{tabular}{ccc}
\hline & \multicolumn{2}{c}{ Relative Release Times } \\
\cline { 2 - 3 } Release Location & Daytime Start & Nighttime Start \\
\hline$R_{1}(\operatorname{rkm} 390)$ & Day 1: $0900 \mathrm{~h}$ & Day 2: $2000 \mathrm{~h}$ \\
$R_{2}(\operatorname{rkm} 307)$ & Day 3: $0900 \mathrm{~h}$ & Day 4: $2000 \mathrm{~h}$ \\
$R_{3}(\operatorname{rkm~275)}$ & Day 4: $2200 \mathrm{~h}$ & Day 5: $0900 \mathrm{~h}$ \\
\hline
\end{tabular}

\subsection{Acoustic Signal Processing}

Transmissions of JSATS tag codes received on cabled and autonomous hydrophones were recorded in raw data files. These files were downloaded periodically and transported to PNNL offices in North Bonneville office and Richland, Washington, for processing. Receptions of tag codes within raw data files were processed to produce a data set of accepted tag detection events. For cabled arrays, detections from all hydrophones at a dam were combined for processing.

The following three filters were used for data from cabled arrays:

- Multipath filter: For data from each individual cabled hydrophone, all tag-code receptions that occur within 0.156 seconds after an initial identical tag code reception were deleted under the assumption that closely lagging signals are multipath. Initial code receptions were retained. The delay of 0.156 seconds was the maximum acceptance window width for evaluating a pulse repetition interval (PRI) and was computed as 2(PRI_Window+12×PRI_Increment). Both PRI_Window and PRI_Increment were set at 0.006 , which was chosen to be slightly larger than the potential rounding error in estimating PRI to two decimal places.

- Multi-detection filter: Receptions were retained only if the same tag code was received at another hydrophone in the same array within 0.3 seconds because receptions on separate hydrophones within 0.3 seconds (about $450 \mathrm{~m}$ of range) were likely from a single tag transmission.

- PRI filter. Only those series of receptions of a tag code (or "messages") that were consistent with the pattern of transmissions from a properly functioning JSATS acoustic tag were retained. Filtering rules were evaluated for each tag code individually, and it was assumed that only a single tag would be transmitting that code at any given time. For the cabled system, the PRI filter operated on a message, which included all receptions of the same transmission on multiple hydrophones within 0.3 seconds. Message time was defined as the earliest reception time across all hydrophones for that message. Detection required that at least six messages were received with an appropriate time interval between the leading edges of successive messages.

Like the cabled-array data, receptions of JSATS tag codes within raw autonomous node data files are processed to produce a data set of accepted tag detection events. A single file is processed at a time, and no information on receptions at other nodes is used. The following two filters are used during processing of autonomous node data:

- Multipath Filter: Same as for the cabled-array data. 
- PRI Filter: Only those series of receptions of a tag code (or "hits") that were consistent with the pattern of transmissions from a properly functioning JSATS acoustic tag were retained. Each tag code was processed individually, and it was assumed that only a single tag would be transmitting that code at any given time.

The output of the filtering processes for both cabled and autonomous hydrophones was a data set of events that summarized accepted tag detections for all times and locations where hydrophones were operating. Each unique event record included a basic set of fields that indicated the unique identification number of the fish, the first and last detection time for the event, the location of detection, and how many messages were detected within the event. This list was combined with accepted tag detections from the autonomous arrays and PIT-tag detections for additional quality assurance/quality control analysis prior to survival analysis. Additional fields capture specialized information, where available. One such example was route of passage, which was assigned a value for those events that immediately precede passage at a dam based on spatial tracking of tagged fish movements to a location of last detection. Multiple receptions of messages within an event can be used to triangulate successive tag position relative to hydrophone locations.

One of the most important quality control steps was to examine the chronology of detections of every tagged fish on all arrays above and below the dam-face array to identify any detection sequences that deviated from the expected upstream to downstream progression through arrays in the river. Except for possible detections on forebay entrance arrays after detection on a nearby dam-face array 1 to $3 \mathrm{~km}$ downstream, apparent upstream movements of tagged fish between arrays that were greater than $5 \mathrm{~km}$ apart or separated by one or more dams were very rare $(<0.015 \%)$ and probably represented false-positive detections on the upstream array. False-positive detections usually will have close to the minimum number of messages and were deleted from the event data set before survival analysis.

Tagged fish in the immediate forebay of The Dalles Dam were tracked in three dimensions to determine routes of passage to estimate SPE and spill + B2CC passage efficiency. Acoustic tracking is a common technique in bioacoustics based on time-of-arrival differences among different hydrophones. Usually, the process requires a three-hydrophone array for 2D tracking and a four-hydrophone array for 3D tracking. For this study, only 3D tracking was performed. The methods were similar to those described by Weiland et al. (2010) for John Day Dam.

\subsection{Statistical Methods}

The estimation of passage survival; tag-life analysis; need for tests of assumptions; and the estimation of travel times, B2CC passage efficiency, SPE, and spill + B2 passage efficiency are described below.

\subsubsection{Estimation of Passage Survival}

Maximum likelihood estimation was used to estimate passage survival for various river reaches that included Bonneville Dam. Capture histories from all virtual releases through three downstream arrays (Figure 2.1), both daytime and nighttime, were pooled for the analysis to produce a single season-wide estimate of survival for each run of fish and river reach of interest. A joint likelihood model was used to estimate dam passage survival based on the virtual single-release models corrected for tag life. All 
single-release survival calculations and tag-life corrections were performed using Program ATLAS (http://www.cbr.washington.edu/paramest/atlas/).

\subsubsection{Tag-Life Analysis}

The 49 acoustic tags systematically sampled from the tags used in the yearling Chinook salmon and steelhead survival studies were monitored continuously until tag failure. Those failure times were fit to the four-parameter vitality model of $\mathrm{Li}$ and Anderson (2009). The vitality model tends to fit acoustic-tag failure times well, because it allows for both early onset of random failure due to manufacturing as well as systematic battery failure later on.

The probability density function for the vitality model can be rewritten as

$$
f(t)=1-\left(\Phi\left(\frac{1-r t}{\sqrt{u^{2}+s^{2} t}}\right)-e^{\left(\frac{2 u^{2} r^{2}}{s^{4}}+\frac{2 r}{s^{2}}\right)} \Phi\left(\frac{2 u^{2} r+r t+1}{\sqrt{u^{2}+s^{2} t}}\right)\right)^{e^{-k t}}
$$

where $\Phi=$ cumulative normal distribution,

$r=$ average wear rate of components,

$S=$ standard deviation in wear rate,

$k=$ rate of accidental failure,

$u=$ standard deviation in quality of original components.

The random failure component, in addition to battery discharge, gives the vitality model additional latitude to fit tag-life data not found in other failure-time distributions such as Weibull or Gompertz. Parameter estimation was based on maximum likelihood estimation.

For the virtual-release group $\left(V_{1}\right)$ based on fish known to have arrived at the dam and with active tags, the conditional probability of tag activation, given the tag was active at the detection array at rkm 234, was used in the tag-life adjustment for that release group. The conditional probability of tag activation at time $t_{1}$, given it was active at time $t_{0}$, was computed by the quotient:

$$
P\left(t_{1} \mid t_{0}\right)=\frac{S\left(t_{1}\right)}{S\left(t_{0}\right)}
$$

\subsubsection{Tests of Assumptions}

\subsubsection{Burnham et al. (1987) Tests}

Tests 2 and 3 of Burnham et al. (1987) have been used to assess whether upstream detection history has an effect on downstream survival. Such tests are most appropriate when fish are physically recaptured or segregated during capture as in the case of PIT-tagged fish going through the juvenile bypass system. However, acoustic-tag studies do not use physical recaptures to detect fish.

Consequently, there is little or no relevance of these tests in acoustic-tag studies. Furthermore, the very high detection probabilities present in acoustic-tag studies frequently preclude calculation of these tests. For these reasons, these tests were not performed. 


\subsubsection{Tests of Mixing}

There were no downstream reference releases of fish downstream of Bonneville Dam and therefore there was no need to test for mixing in the common tailwater.

\subsubsection{Tagger Effects}

Subtle differences in handling and tagging techniques can have an effect on the survival of acoustictagged smolts used in the estimation of dam passage survival. For this reason, tagger effects on juvenile steelhead and yearling Chinook salmon smolts were evaluated as part of the compliance study at The Dalles Dam (Skalski et al. 2010a).

\subsubsection{Estimation of Travel Times}

We calculated median and mean travel times associated with forebay residence time, 100-m forebay residence time, tailrace egress time, and project passage time. A few fish with high travel times tended to bias means upward relative to median estimates. The variance in $\bar{t}$ was estimated by

$$
\xi \operatorname{ar}(\bar{t})=\frac{\sum_{i=1}^{n}\left(t_{i}-\bar{t}\right)^{2}}{n(n-1)}
$$

where $t_{i}$ was the travel time of the $i^{\text {th }}$ fish $(i=1, \mathrm{~K}, n)$.

Methods for estimating travel times were as follows:

1. Forebay residence time was calculated by subtracting the time of last detection on the dam-face array from the time of first detection on the forebay entrance array.

2. The 100-m forebay residence time was calculated by subtracting the time of last detection at the dam face from the time of first detection $100 \mathrm{~m}$ upstream of the dam face.

3. Tailrace egress time was calculated by subtracting the time of last detection at the dam-face array from the time of last detection at the tailrace exit array downstream of the dam.

4. Project passage time was calculated by subtracting the time of first detection on the forebay entrance array from the time of last detection on the tailrace egress array.

\subsubsection{Estimation of B2CC Passage Efficiency}

The passage efficiency of the B2CC for each run was estimated relative to absolute numbers passing B2:

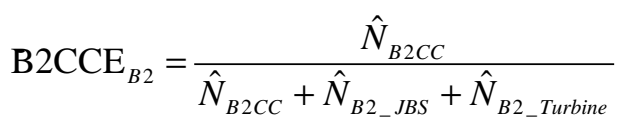


where $\hat{N}_{B 2 C C}$ is the estimated abundance of acoustic-tagged fish through the B2CC; $\hat{N}_{B 2 \_J B S}$ is the estimated abundance of fish passing through the B2 juvenile bypass system; and $\hat{N}_{B 2 \_ \text {Turbine }}$ is the estimated abundance of fish passing through B2 turbines. A double-detection array was used to estimate absolute abundance $(N)$ through a route using the single mark-recapture model (Seber 1982:60) independently at each route. Calculating the variance in stages, the variance of B2CCE was estimated as follows:

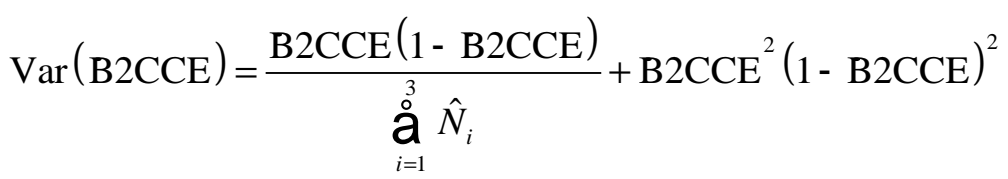

$$
\begin{aligned}
& {\left[\frac{\operatorname{Var}\left(\hat{N}_{B 2 C C}\right)}{\left(\hat{N}_{B 2 C C}\right)^{2}}+\frac{\sum \operatorname{ar}\left(\hat{N}_{B 2_{-} J B S}\right)}{\hat{N}_{J B S}^{2}}+\frac{\sum \operatorname{ar}\left(\hat{N}_{B 2 \_ \text {Turbine }}\right)}{\hat{N}_{B 2 \_ \text {Turbine }}^{2}}\right] .}
\end{aligned}
$$

\subsubsection{Estimation of Spill Passage Efficiency}

Traditionally, SPE is the number of fish passing the spillway divided by the number passing the entire dam. SPE was estimated by the fraction

$$
\xi \mathrm{PE}=\frac{\hat{N}_{S P}}{\hat{N}_{S P}+\hat{N}_{P H}}
$$

where $\hat{N}_{i}$ is the estimated abundance of acoustic-tagged fish through the $i$ th route ( $i=$ spillway [SP], or powerhouse $[\mathrm{PH}])$. The double-detection array was used to estimate absolute abundance $(N)$ through a route using the single mark-recapture model (Seber 1982:60) independently at each route. Calculating the variance in stages, the variance of $\& \mathrm{PE}$ was estimated as

$$
\begin{aligned}
\operatorname{Var}(\xi \mathrm{PE})= & \frac{\xi \mathrm{PE}(1-\xi \mathrm{PE})}{\sum_{i=1}^{3} \hat{N}_{i}}+\xi \mathrm{PE}^{2}(1-\xi \mathrm{PE})^{2} \\
& \cdot\left[\frac{\operatorname{Var}\left(\hat{N}_{S P}\right)}{\left(\hat{N}_{S P}\right)^{2}}+\frac{\xi_{\operatorname{Lar}}\left(\hat{N}_{P H}\right)}{\hat{N}_{P H}^{2}}\right] .
\end{aligned}
$$

\subsubsection{Estimation of Spill + B2CC Passage Efficiency}

By definition in the Fish Accords, another metric is required and that is the number of fish passing the spillway and the B2CC divided by the number passing the dam. It is estimated as follows:

$$
\S_{S p i l l+B 2 C C}=\frac{\left(\hat{N}_{S P}+\hat{N}_{B 2 C C}\right)}{\hat{N}_{S P}+\hat{N}_{P H}}
$$


where $\hat{N}_{i}$ is the estimated abundance of acoustic-tagged fish through the $i$ th route ( $i=$ spillway [SP], the B2CC, or B1 and B2 combined [PH]). The double-detection array was used to estimate absolute abundance $(N)$ through a route using the single mark-recapture model (Seber 1982:60) independently at each route. Calculating the variance in stages, the variance of \& $\mathrm{PE}$ was estimated as follows:

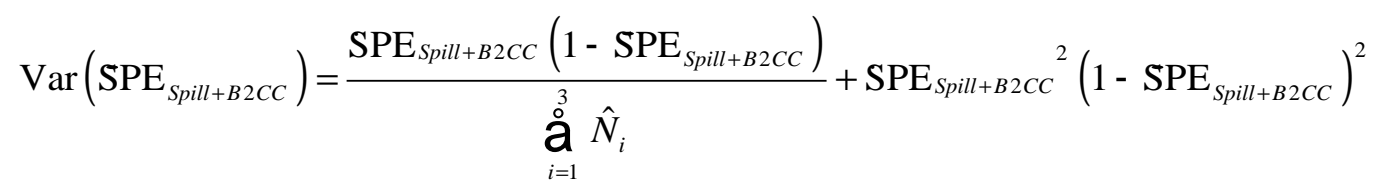

$$
\begin{aligned}
& \cdot\left[\frac{\operatorname{Var}\left(\hat{N}_{S P}+\hat{N}_{B 2 C C}\right)}{\left(\hat{N}_{S P}+\hat{N}_{B 2 C C}\right)^{2}}+\frac{\xi \operatorname{ar}\left(\hat{N}_{P H}\right)}{\hat{N}_{P H}^{2}}\right] .
\end{aligned}
$$





\subsection{Results}

Results are described for discharge and spill conditions, the assessment of study assumptions, tagger effects, reach and release-specific survival estimates, forebay and 100-m forebay residence times, tailrace egress times, project passage time, and estimates of SPE.

\subsection{Discharge and Spill Conditions}

Total project discharge during the spring survival study at Bonneville Dam was lower than the average for the previous 10-year period before June 3 and higher than the average from June 4 through June 13 (Figure 3.1). Daily spill discharge was within $25 \mathrm{kcfs}$ of the average for the previous 10 years until June 6 and higher than the average after June 6.

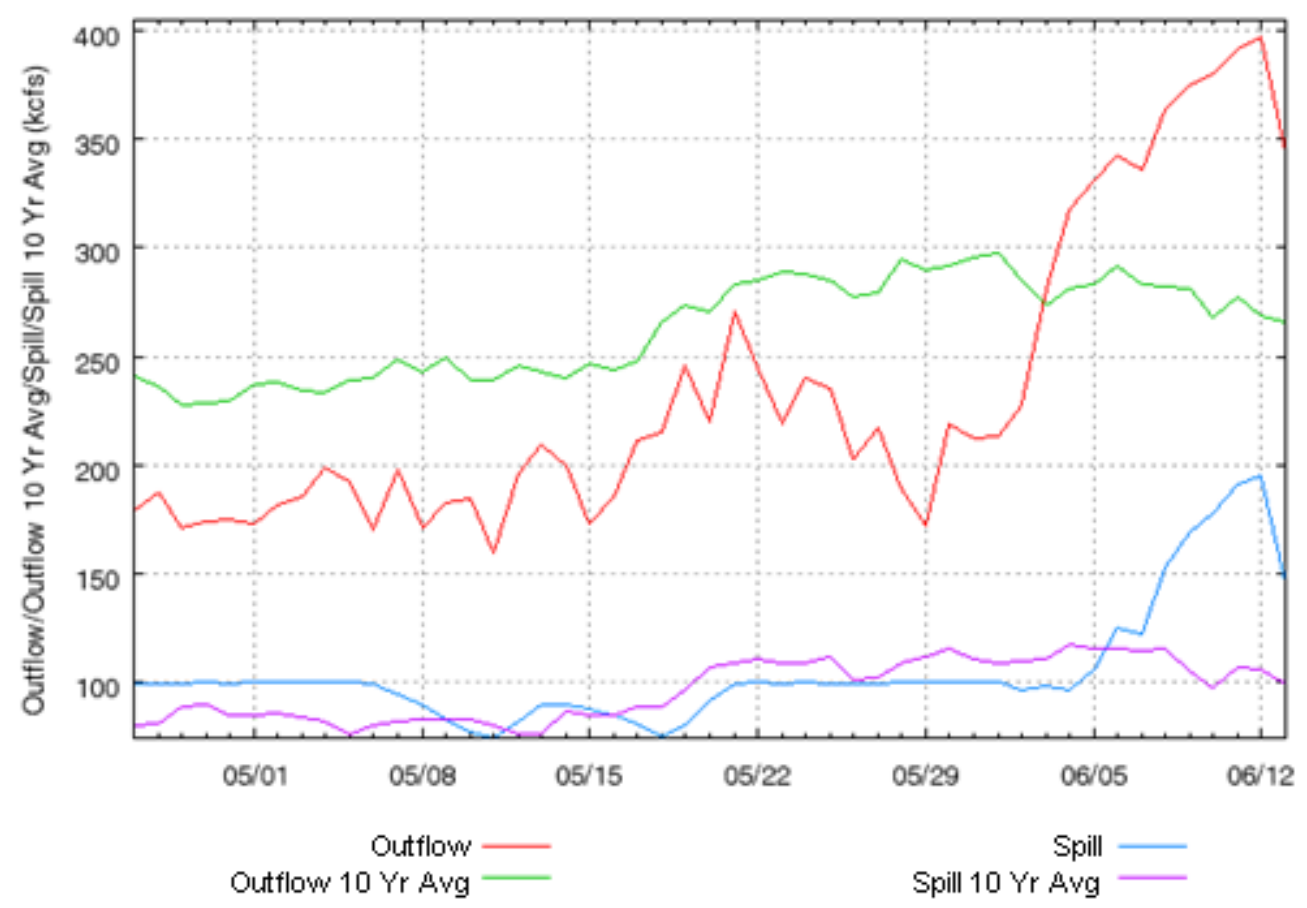

Figure 3.1. Daily Outflow and Spill Discharge of Water from Bonneville Dam for the Period from April 26 Through June 13, 2010 (Labeled Outflow and Spill) and 10-year Averages from 2000 Through 2009.

\subsection{Assessment of Assumptions}

The assessment of assumptions covers fish size distribution, tag-life-corrections, handling mortality, tag shedding, tagger effects, and arrival distributions relative to tag life. Mixing of fish releases was not a consideration in 2010 because there were no reference releases of fish downstream of the dam. 


\subsubsection{Fish Size Distribution}

Comparison of acoustic-tagged fish with ROR fish sampled at John Day Dam through the Smolt Monitoring Program shows that the length frequency distributions were generally well matched for yearling Chinook salmon and steelhead (Figure 3.2). For steelhead, the upper size limit for the tagged fish was $260 \mathrm{~mm}$, and none of the very large fish (>260 mm) were tagged. Median length for acoustictagged yearling Chinook salmon was $153 \mathrm{~mm}$. For steelhead smolts, the median length of the tagged fish was $214 \mathrm{~mm}$.

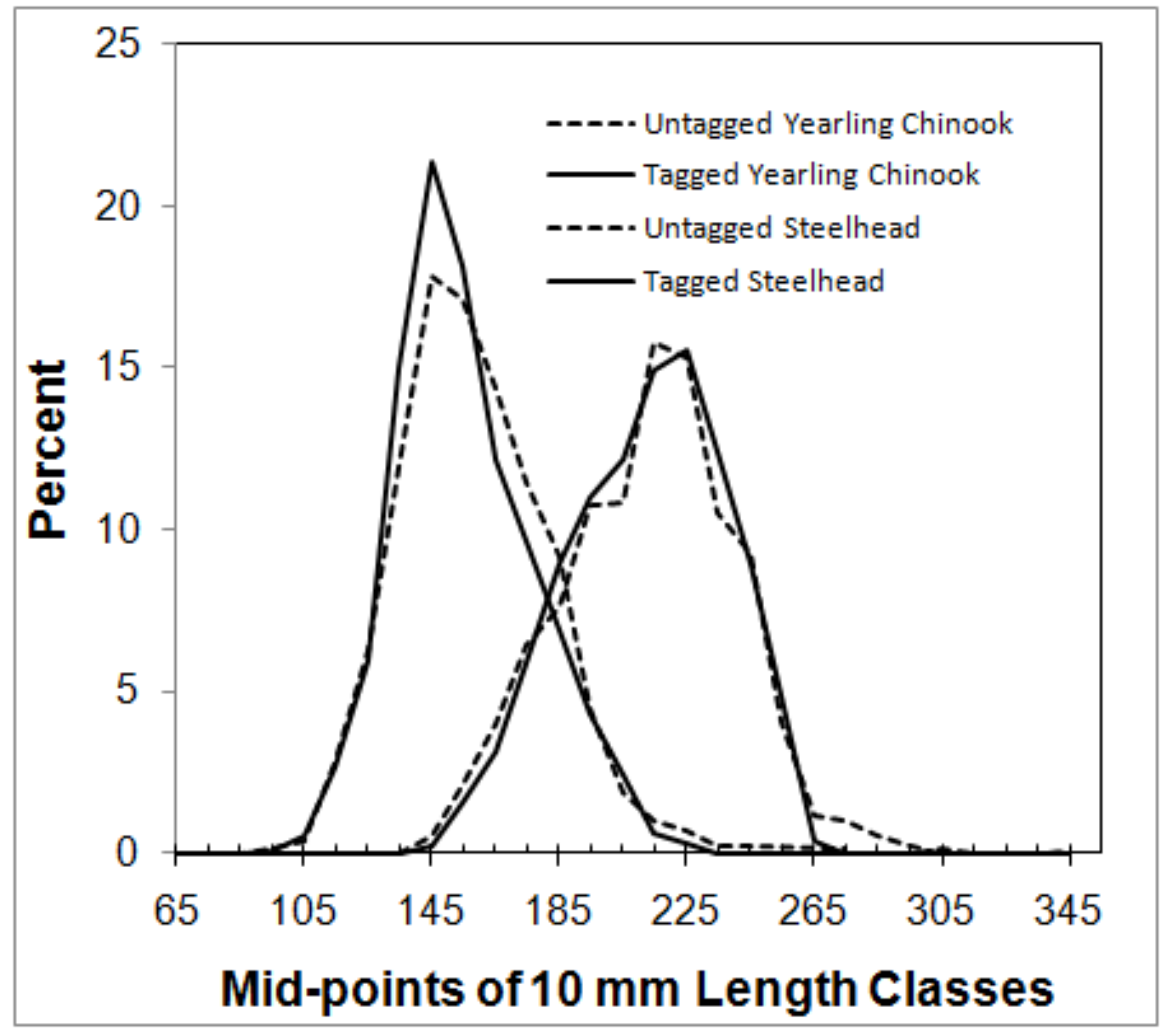

Figure 3.2. Comparison of Length Frequency Distributions of Tagged and Untagged Fish Passing the John Day Dam Smolt Monitoring Facility

\subsubsection{Tag-Life Corrections}

Mean tag life $(n=49)$ was 33.13 days. The earliest tag failure was at 7.8 days, and the last failure occurred at 39.59 days. The failure-time data for the acoustic tags was fit to a four-parameter vitality model of Li and Anderson (2009). The maximum likelihood estimates for the four model parameters where $\hat{r}=0.02963(\mathrm{SE}<0.00001), \hat{S}=-5.59145 \times 10^{-10}(\mathrm{SE}<0.00001), \hat{k}=0.001733(\mathrm{SE}=0.00128)$, and $\hat{u}=0.0572979(\hat{\mathrm{E}}=0.00732)$ (Figure 3.3). This tag-life survivorship model was subsequently used to estimate the probabilities of tag failure and provide tag-life-adjusted estimates of smolt survival. 


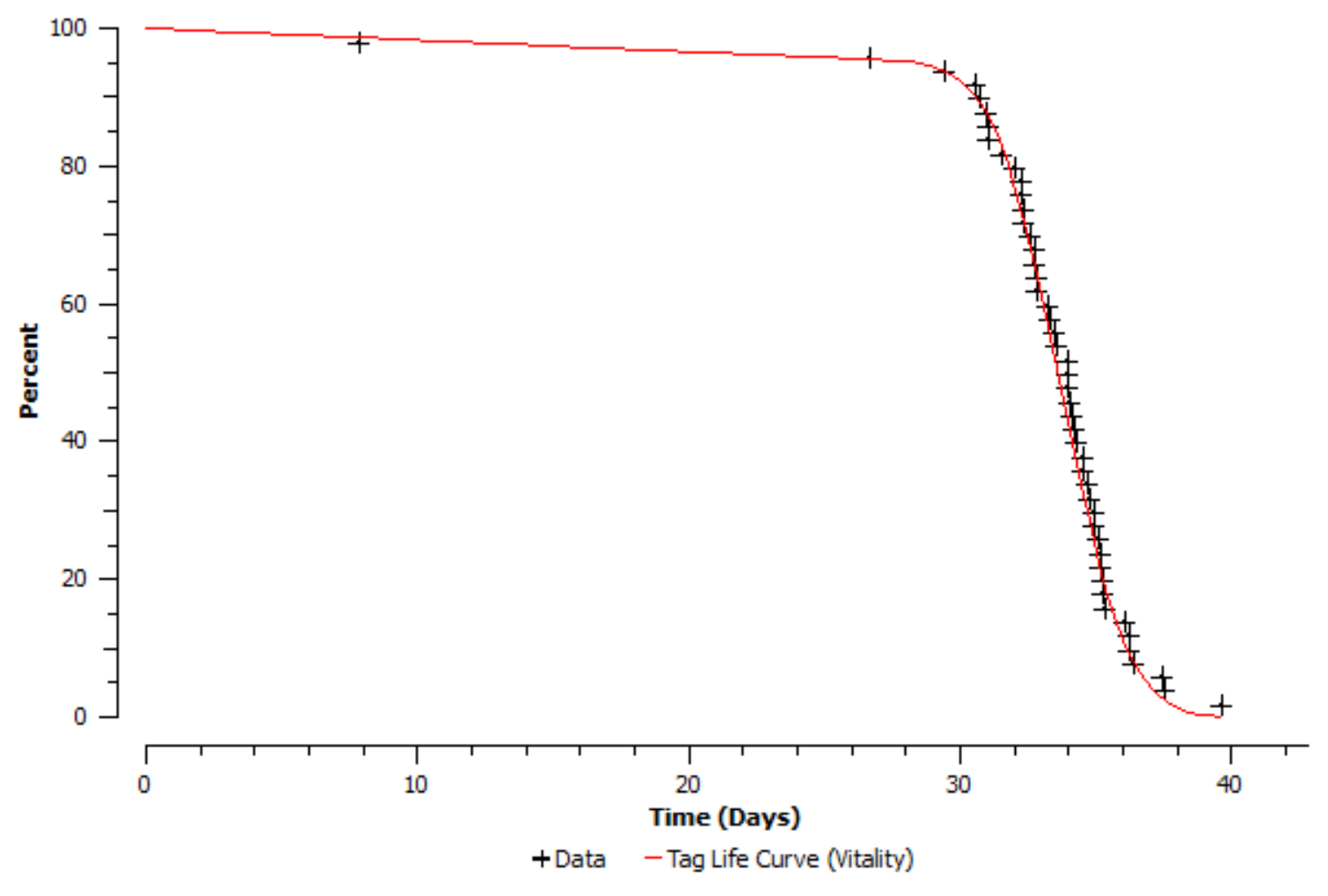

Figure 3.3. Individual Failure Times for the $n=49$ Acoustic Tags Used in the Tag-Life Study, Along with the Fitted 4-Parameter Vitality Model of Li and Anderson (2009)

\subsubsection{Handling Mortality and Tag Shedding}

Fish were held for 24 hours prior to release. The 24-h tagging mortality in spring was $0.20 \%$. No tags were shed during the 24-h holding period.

\subsubsection{Tagger Effects}

No tagger effects on survival were observed during the spring 2010 study (Skalski et al. 2010a).

\subsubsection{Arrival Distributions}

The estimated probability an acoustic tag was active when fish arrived at a downstream detection array depends on the tag-life curve and the distribution of observed travel times. These probabilities were calculated by integrating the tag survivorship curve (Figure 3.3) over the observed distribution of fish arrival times (i.e., time from tag activation to arrival).

The last distinct detection array used in the survival analysis was rkm 86. Plots of the arrival distributions of fish to the dam-face array and the three survival detection arrays indicate that most juvenile steelheads (Figure 3.4) and yearling Chinook salmon smolts (Figure 3.5) passed all arrays well before tag failure became problematic. Tag-life adjustments to survival estimates would be incomplete if fish had arrival times beyond the range of observed tag lives. 


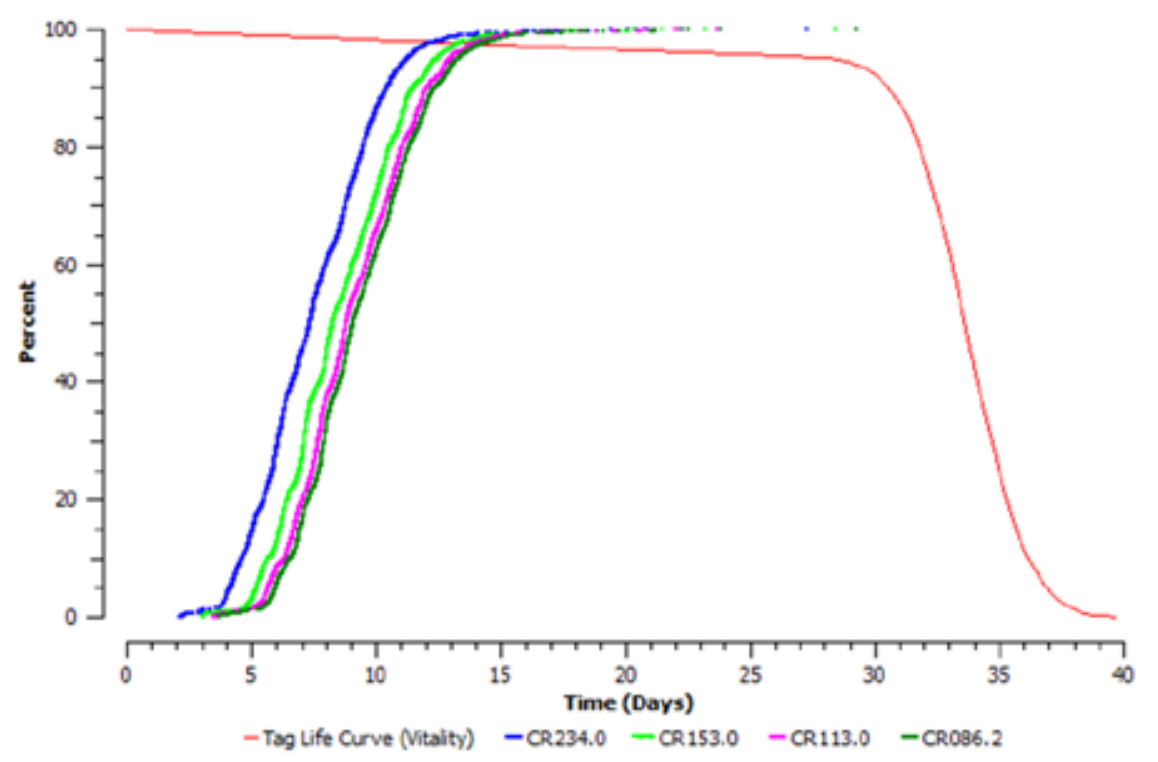

Figure 3.4. Cumulative Time of Arrival of Tagged Juvenile Steelheads Regrouped at the Bonneville Dam Faces to Form a Virtual Dam-Passage Release at All Downstream Detection Sites Versus Tag-Life Curve

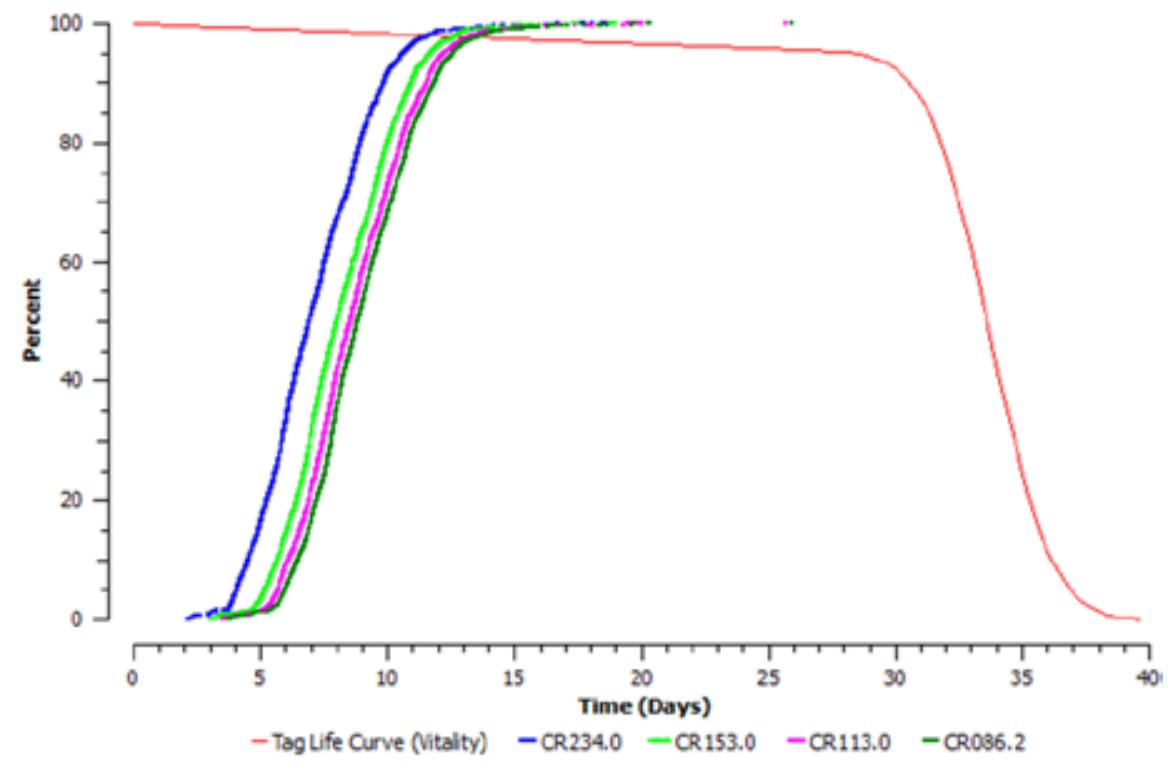

Figure 3.5. Cumulative Time of Arrival of Tagged Yearling Chinook Salmon Smolts Regrouped at the Bonneville Dam Faces to Form a Virtual Dam-Passage Release at All Downstream Detection Sites Versus Tag-Life Curve

\subsection{Examination of Tagger Effects}

Having various fish handlers tag the same proportions of fish for release at each of the release sites helped minimize, but did not necessarily eliminate, handling effects in the survival study. The study was therefore designed to balance tagger effort across locations. Implementation produced near perfect balance for the releases of both the yearling Chinook salmon (Skalski et al. 2010a). 
To further assess whether tagger effects may have occurred, reach survivals for the fish tagged by the different staff were calculated using the Cormack-Jolly-Seber single-release-recapture model. For both yearling Chinook salmon and steelhead, reach survivals were found to be homogeneous $(P>0.05)$ across all reaches examined (Skalski et al. 2010a). For this reason, all fish, regardless of fish tagger, were included in the survival analyses.

\subsection{Estimates of Reach Survival and Release-Specific Survival}

The estimates of reach passage survival were based on the single-release design using capture-history data and the fitted tag-life curve (Figure 3.3). The appendix lists the details of all tag-life-corrected, virtual single release detection and survival results in this report based on pooling data from the three releases of acoustically tagged fish upstream of Bonneville Dam (R1, R2, and R3). For each run of fish studied, we compared release-specific estimates of virtual-release survival graphically to determine whether pooling fish from the three releases upstream of Bonneville Dam was appropriate. Based on overlapping 95\% confidence intervals for point estimates from the three release sites (Figure 3.6), we concluded it was acceptable to pool fish from all three releases to form virtual releases at the forebay entrance array and at the dam-face array.

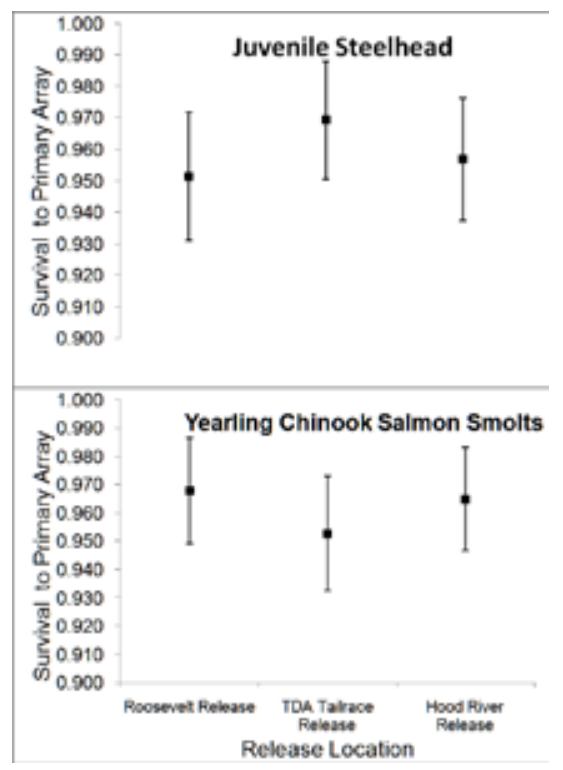

Figure 3.6. Plot Comparing Virtual-Release Dam-Passage Survival Estimates Among the Three Releases of Fish Upstream of Bonneville Dam in 2010. Error bars indicate 95\% confidence limits.

\subsubsection{Yearling Chinook Salmon}

The estimate of dam passage survival was based on the survival of V1 to detection array D1. Using the tag-life-adjusted survival estimates for yearling Chinook salmon smolts and the capture-history data listed in the appendix, dam passage and reach survival to $81 \mathrm{~km}$ downstream of Bonneville Dam was calculated to be $0.952(\mathrm{SE}=0.0040)$. The standard error is based on both the multinomial sampling error of the release-recapture process and the sampling error associated with the estimation of the probabilities 
of tag activation. This was not an official compliance test requiring paired reference releases, but singlerelease estimates still exceeded the $\mathrm{BiOp}$ requirement of 0.96.

We also estimated survival from the forebay entrance array (CR236.0) to the primary array (CR153.0). In a formal compliance test with reference releases, this estimate would be from the forebay entrance array to the tailrace exit array, but this was not possible in 2010. For yearling Chinook salmon smolts, survival from the forebay array to the primary array was $0.951(3 \mathrm{E}=0.0040)$. The difference between the forebay entrance and the dam-face estimates was $0.06 \%$, which presumably resulted from mortality of fish in the forebay of Bonneville Dam. Details of tag-life corrections, capture histories, and survival estimates are presented in the appendix.

\subsubsection{Steelhead}

Using the tag-life-adjusted survival estimate for the three release groups and the capture-history data listed in the appendix, the virtual single release, tag-life-corrected estimate of dam-passage survival for steelhead smolts at Bonneville Dam was estimated to be $0.945(\mathrm{SE}=0.0043)$. This single-release estimate for steelhead was very close to the BiOp requirement and may have met the requirement had there been reference releases.

The tag-life corrected, virtual single release survival of juvenile steelhead from the forebay entrance array down to the primary survival detection array was 0.944 ( $\mathrm{SE}=0.0043$ ). The difference between the forebay entrance and the dam-face estimates was $0.03 \%$, which presumably resulted from mortality in the forebay of Bonneville Dam. Details of tag-life corrections, capture histories, and survival estimates are presented in the appendix.

\subsection{Forebay Residence Time}

The forebay residence time, calculated as the time elapsed from the first detection on the forebay entrance array until the last detection on the dam-face array, was higher for juvenile steelhead (median $=1.687$; mean $=4.219 ; \mathrm{SE}=0.1120)$ than it was for yearling Chinook salmon smolts (median $=0.743 ;$ mean $=1.268 ; \mathrm{S}=0.0456$ ).

\subsection{0-m Forebay Residence Time}

The 100-m forebay residence times were based on the time elapsed from the first detection within $100 \mathrm{~m}$ of the dam face to the last detection at the double array in front of Bonneville Dam. The timing of the first detection within $100 \mathrm{~m}$ of the dam was based on 3D tracking of the acoustic-tagged fish and interpretation of the time when the fish first crossed the 100-m distance threshold.

Median and mean residence times for yearling Chinook salmon smolts were estimated to be 0.178 and 1.844 hours, respectively ( $\partial_{E}=0.2675$ ). For steelhead smolts, median and mean forebay residence times were estimated to be 1.426 and 6.060 hours, respectively ( $\mathrm{SE}_{\mathrm{E}} \mathbf{0 . 5 6 6 4}$ ). 


\subsection{Tailrace Egress Time}

Median and mean tailrace egress times for yearling Chinook salmon smolts were estimated to be 0.455 and 0.943 hours, respectively ( $\mathrm{SE}=0.1042$ ). For steelhead smolts, median and mean tailrace egress times were estimated to be 0.414 and 1.121 hours, respectively ( $\mathrm{SE}=0.1351$ ).

\subsection{Project Passage Time}

Project passage time is defined as the time from the last detection on the forebay entrance array $2 \mathrm{~km}$ upstream of B2 to the time of first detection at the tailrace egress array, regardless of passage route.

Median and mean project passage times for tagged yearling Chinook salmon smolts were estimated to be 1.290 and 2.213 hours, respectively ( $S E=0.1142$ ). For juvenile steelhead, median and mean project passage times were estimated to be 2.397 and 5.316 hours, respectively ( $\mathrm{SE}=0.1765$ ).

\subsection{Estimates of Spill Passage Efficiency}

Spill passage efficiency is defined as the fraction of fish that passed through the spillway divided by the number of fish passing the entire dam. The double-detection array at the face of Bonneville Dam was used to identify and track fish as they entered the forebay. Using absolute passage estimates, the number of fish entering the spillway and powerhouse were used to estimate SPE using a binomial sampling model. For yearling Chinook smolts

$$
\xi_{\mathrm{P}} \mathrm{E}_{C H}=0.528(\mathrm{SE}=0.0086)
$$

and for juvenile steelhead

$$
\delta_{\mathrm{PE}}=0.406\left(\mathrm{SE}_{S T}=0.0085\right) .
$$

The 2008 Fish Accords specify another measure for Bonneville Dam-the combined efficiency of spillway and B2CC - which is the number of fish passing the spillway and B2CC divided by the number of fish that passed the entire dam (i.e., spillway + B2CC passage efficiency). For yearling Chinook smolts

$$
\mathrm{B} 2 \mathrm{CC}_{C H}=0.717(\mathrm{SE}=0.0078)
$$

and for juvenile steelhead

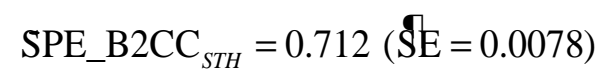





\subsection{Discussion}

This section briefly discusses the reasonableness of primary survival model assumptions, the historical context for estimates, and the statistical performance of the double array and spill-treatment comparisons.

\subsection{Reasonableness of Model Assumptions}

The survival study at Bonneville Dam was a precursor to a full-scale application of the virtual/pairedrelease design of Skalski et al. (2010b) in the FCRPS in 2011, but the single-release survival model used in this study has some of the same assumptions as the virtual/paired-release design.

Overall, the primary assumptions of the single-release survival model used for this study were reasonable. Auxiliary analyses found no tagger effects that might confound estimation of dam passage survival (Skalski et al 2010). Travel times were also sufficiently short relative to tag life to adequately adjust the release-recapture data for tag failure. In all cases, the probability that an acoustic tag was active at a downstream detection location was $>0.98$. The distribution of fish lengths for steelhead smolts used in the tagging study was comparable to the ROR steelhead sampled at John Day Dam by the Fish Passage Center (FPC). For yearling Chinook salmon, fewer small fish and fewer big fish were used in the tagging study than in the observed length frequency distribution sampled at John Day Dam by the FPC. Overall, the spring 2010 acoustic-tag studies at Bonneville Dam appear to have been well executed and without flaws that could negate study results.

In this precursor year to compliance testing, detection data from the first three downstream detection arrays were used in the survival analyses. We could have used all arrays downstream of the dam instead of just the first three arrays, but estimates from both methods were similar. In future years, we likely will continue to use only the three nearest downstream hydrophone arrays to estimate survival. This will keep procedures simple and avoid any perception that specific array combinations were selected preferentially.

\subsection{Historical Context}

There are no historical survival rates that are exactly comparable to the estimates made for spring 2010. Historical estimates covered different river reaches than those used in 2010, and often were based on fish with different tag burdens that were released at different locations upstream of the dam. This is not to say that comparisons to historical estimates would be meaningless or lack instructional value; it is to say that every comparison differs in precision. Paired-release estimates relative to the survival of fish passing the B2CC in 2008 and 2009 were similar to the 2010 estimate (Table 4.1). Estimates made by radio telemetry in 2004 and 2005 also were as high as or higher than the 2010 estimates made using acoustic telemetry.

Historically, forebay residence times were calculated for each dam structure at Bonneville as the time from first detection by radio telemetry (presumably about $100 \mathrm{~m}$ from antennas) until the time of passage through the dam. Estimates summarized by Ploskey et al. (2007) for juvenile steelhead were $5.4 \mathrm{~h}$ for B1, 0.3 for the spillway and $3.0 \mathrm{~h}$ for B2. The average of those mean estimates for juvenile steelhead was $2.9 \mathrm{~h}$, and this was $48 \%$ of the mean estimate of $6.01 \mathrm{~h}$ in 2010 . About $40 \%$ of the steelhead in the 2010 sample was detected in the B1 forebay, which was acoustically quiet relative to the spillway and B2 
forebays, and this high proportion likely biased the 2010 estimate high. The median for steelhead in 2010 was $1.42 \mathrm{~h}$. Estimates summarized by Ploskey et al. (2007) for yearling Chinook salmon were $2.2 \mathrm{~h}$ for B1, 0.2 for the spillway, and 0.5 for B2. The average of those mean estimates $(0.97 \mathrm{~h})$ was about $52 \%$ of the 2010 estimate for yearlings $(1.87 \mathrm{~h}$ ), which likely was biased high by having $43 \%$ of the sample from the B1 forebay, where range of detection was high. The median forebay residence time for yearlings was just $0.17 \mathrm{~h}$ in 2010 .

Table 4.1. Comparison of Paired-Release Passage Survival Estimates for 2004, 2005, 2008, 2009, and 2010. Estimates for 2008, 2009, and 2010 are survival rates relative the survival of fish passing through the B2CC, whereas the 2004 and 2005 estimates are relative to the survival of fish in tailrace reference releases.

\begin{tabular}{lc}
\hline \multicolumn{1}{c}{ River Reach } & $\begin{array}{c}\text { Paired } \\
\text { Estimate }\end{array}$ \\
\hline \multicolumn{1}{c}{ Steelhead Estimates } \\
\hline 2004 (Counihan et al. 2006a) & 0.991 \\
2005 (Counihan et al. 2006b) & 0.963 \\
2008 (CR237 to CR203) and (tailrace to CR203) & 0.972 \\
2009 (CR236 to CR192) and (B2CC to CR192) & 0.970 \\
2010 (CR236 to CR153) and (B2CC to CR153) & 0.969 \\
\hline \multicolumn{2}{c}{ Yearling Chinook Estimates } \\
\hline 2004 (Counihan et al. 2006a) & 0.951 \\
2005 (Counihan et al. 2006b) & 0.966 \\
2008 (CR237 to CR203) and (tailrace to CR203) & 0.969 \\
2009 (CR236 to CR192) and (B2CC to CR192) & 0.962 \\
2010 (CR236 to CR153) and (B2CC to CR153) & 0.961 \\
\hline
\end{tabular}

Holmberg et al. (2001) estimated median egress times from the forebay to the B2 outfall vicinity for juvenile steelhead that passed B1 $(0.41 \mathrm{~h})$ and the spillway $(0.43 \mathrm{~h})$, and those egress times were reasonably close to our median estimate of $0.42 \mathrm{~h}$ for spring 2010. Holmberg et al. (2001) also estimated median egress times from the forebay to the B2 outfall vicinity for yearling Chinook salmon that passed B1 $(0.49 \mathrm{~h})$ and the spillway $(0.41 \mathrm{~h})$, and those egress times were reasonably close to our median estimate of $0.46 \mathrm{~h}$ for yearlings in spring 2010. Holmberg et al. (2001) estimated median egress times from the forebay to the B2 outfall vicinity for subyearling Chinook that passed B1 $(0.40 \mathrm{~h})$ and the spillway (0.41), and those egress times were close to our median estimate of $0.42 \mathrm{~h}$.

Historical estimates of SPE for non-drought spring periods ranged from 0.26 to 0.55 for juvenile steelhead and from 0.33 to 0.57 for yearling Chinook salmon (summarized by Ploskey et al. 2007). The spring 2010 estimate of SPE was 0.397 for steelhead and 0.519 for yearling Chinook salmon, and both of these estimates fall within the respective historical ranges for non-drought years.

\subsection{Statistical Performance}

The full-dam single-release survival study at Bonneville Dam in 2010 was a precursor to a full-scale application of the virtual/paired-release design planned for the dam in 2011. The double array at each dam face provided a combined detection probability of 1.0, and this indicates that dam-face deployments are ready for the full BiOp study in 2011. 


\subsection{References}

3 Treaty Tribes-Action Agencies. 2008. Memorandum of Agreement Among the Umatilla, Warm Springs and Yakama Tribes, Bonneville Power Administration, U.S. Army Corps of Engineers, and U.S. Bureau of Reclamation, Portland, Oregon, April 4, 2008. Available at http://www.salmonrecovery.gov/Files/BiologicalOpinions/MOA_ROD.pdf.

Burnham, KP, DR Anderson, GC White, C Brownie, and KH Pollock. 1987. "Design and analysis methods for fish survival experiments based on release-recapture.” American Fisheries Society Monograph 5.

Counihan, TD, J Hardiman, C Walker, A Puls, and G Holmberg. 2006a. Survival Estimates of Migrant Juvenile Salmonids through Bonneville Dam using Radio Telemetry, 2004. Annual Report by the U.S. Geological Survey, Columbia River Research Laboratory, Cook, Washington, for the U.S. Army Engineer District, Portland, Oregon.

Counihan, TD, J Hardiman, C Walker, A Puls, and G Holmberg. 2006b. Survival Estimates of Migrant Juvenile Salmonids through Bonneville Dam using Radio Telemetry, 2005. Annual Report by the U.S. Geological Survey, Columbia River Research Laboratory, Cook, Washington, for the U.S. Army Engineer District, Portland, Oregon.

Holmberg, GS, R E Wardell, MG Mesa, NS Adams, and DW Rondorf. 2001. Evaluation of the Bonneville Dam Second Powerhouse new Juvenile Bypass System, 1999. Annual Report by U.S. Geological Survey, Columbia River Research Laboratory, Cook, Washington for the U.S. Army Engineer District, Portland, Oregon.

Li, T and JJ Anderson. 2009. "The vitality model: A way to understand population survival and demographic heterogeneity.” Theoretical Population Biology 76:118-131.

Martinson, R, G Kovalchuk, and D Ballinger. 2006. "Monitoring of downstream salmon and steelhead at federal hydroelectric facilities." 2005-2006 Annual Report, Project No. 198712700, BPA Report DOE/BP-00022085-2, Bonneville Power Administration, Portland, Oregon.

NOAA (National Atmospheric and Oceanic Administration) Fisheries. 2008. Biological OpinionConsultation on Remand for Operation of the Federal Columbia River Power System, 11 Bureau of Reclamation Projects in the Columbia Basin and ESA Section 10(a)(1)(A) Permit for Juvenile Fish Transportation Program. National Marine Fisheries Service (NOAA Fisheries) - Northwest Region, Seattle, Washington. Available at: http://www.salmonrecovery.gov/.

Ploskey, GR, GE Johnson, AE Giorgi, RL Johnson, JR Stevenson, CR Schilt, PN Johnson, and DS Patterson. 2007. Synthesis of Biological Reports on Juvenile Fish Passage and Survival at Bonneville Dam, 1939-2005. PNNL-15041, Pacific Northwest National Laboratory, Richland, Washington.

Seber, GAF. 1982. The Estimation of Animal Abundance. MacMillan, New York. 
Skalski, JR, GE Johnson, TJ Carlson. 2010a. Compliance Monitoring of Juvenile Yearling Chinook Salmon and Steelhead Survival and Passage at The Dalles Dam, Spring 2010. Summary Report PNNL19819, Pacific Northwest National Laboratory, Richland, Washington.

Skalski, JR, RL Townsend, TW Steig, and S Hemstrom. 2010b. "Comparison of two alternative approaches for estimating dam passage survival using acoustic-tagged sockeye salmon smolts.” North American Journal of Fisheries Management 30:831-839.

Townsend, RL, JR Skalski, P Dillingham, and TW Steig. 2006. "Correcting bias in survival estimation resulting from tag failure in acoustic and radiotelemetry studies." Journal of Agricultural Biology and Environmental Statistics 11(2):183-196.

Weiland, MA, GR Ploskey, JS Hughes et al. 2010. Acoustic Telemetry Evaluation of Juvenile Salmonid Passage and Survival Proportions at John Day Dam, 2009. PNNL-19422, draft final report submitted to the U.S. Army Corps of Engineers, Portland District, Portland, Oregon, by Pacific Northwest National Laboratory, Richland, Washington. 
Appendix A

Capture Histories, Tag-Life-Corrected Survival Estimates, and Capture Probabilities 



\section{Appendix A - Capture Histories, Tag-Life-Corrected Survival Estimates, andCapture Probabilities}

Table A.1. Bonneville Dam Passage Capture History for Yearling Chinook Salmon

\begin{tabular}{ccccccccc}
\hline & 111 & 011 & 101 & 001 & 110 & 010 & 100 & 000 \\
\hline Number of Fish & 2278 & 525 & 141 & 44 & 121 & 48 & 27 & 174 \\
\hline
\end{tabular}

Table A.2. Bonneville Dam Passage Survival and Detection Detail for Yearling Chinook Salmon Survival Detail:

\begin{tabular}{|l|c|c|c|c|}
\hline & \multicolumn{2}{|c|}{ CR234.0 to CR153.0 } & \multicolumn{2}{c|}{ CR153.0 to CR113.0 } \\
\hline & Estimate & s.e. $†$ & Estimate & s.e. $^{*}$ \\
\hline Yearling Chinook - All Upstream Releases & 0.9519 & 0.003968 & 0.9938 & 0.002057 \\
\hline
\end{tabular}

Capture Detail:

\begin{tabular}{|l|c|c|c|c|c|c|}
\hline & \multicolumn{2}{|c|}{ CR153.0 } & \multicolumn{2}{c|}{ CR113.0 } & \multicolumn{2}{c|}{ CR086.2 Survival*Capture } \\
\hline & Estimate & s.e.* & Estimate & s.e.* & Estimate & s.e.* \\
\hline Yearling Chinook - All Upstream Releases & 0.8046 & 0.007057 & 0.9381 & 0.004409 & 0.9437 & 0.004250 \\
\hline
\end{tabular}

* Standard error is based on the inverse Hessian.

† Standard error is based on bootstrapping.

Table A.3. Forebay Virtual Release Capture History for Yearling Chinook Salmon

\begin{tabular}{cccccccccc}
\hline & 111 & 011 & 101 & 001 & 110 & 010 & 100 & 000 \\
\hline Number of Fish & 2287 & 527 & 142 & 44 & 121 & 48 & 27 & 177 \\
\hline
\end{tabular}

Table A.4. Forebay Virtual Release Survival and Detection Detail for Yearling Chinook Salmon Survival Detail:

\begin{tabular}{|l|c|c|c|c|}
\hline & \multicolumn{2}{|c|}{ CR236.0 to CR153.0 } & CR153.0 to CR113.0 \\
\hline & Estimate & s.e. $\dagger$ & Estimate & s.e. $^{*}$ \\
\hline Yearling Chinook - All Upstream Releases & 0.9513 & 0.004014 & 0.9939 & 0.002049 \\
\hline
\end{tabular}

\section{Capture Detail:}

\begin{tabular}{|c|c|c|c|c|c|c|}
\hline & \multicolumn{2}{|c|}{ CR153.0 } & \multicolumn{2}{|c|}{ CR113.0 } & \multicolumn{2}{|c|}{ CR086.2 Survival*Capture } \\
\hline & Estimate & s.e.* & Estimate & s.e.* & Estimate & s.e.* \\
\hline Yearling Chinook - All Upstream Releases & 0.8047 & 0.007043 & 0.9380 & 0.004403 & 0.9439 & 0.004235 \\
\hline
\end{tabular}

* Standard error is based on the inverse Hessian.

† Standard error is based on bootstrapping. 
Table A.5. Bonneville Dam Passage Capture History for Juvenile Steelhead

\begin{tabular}{ccccccccc}
\hline & 111 & 011 & 101 & 001 & 110 & 010 & 100 & 000 \\
\hline Number of Fish & 2089 & 642 & 140 & 72 & 148 & 41 & 36 & 205 \\
\hline
\end{tabular}

Table A.6. Bonneville Dam Passage Survival and Detection Detail for Juvenile Steelhead Survival Detail:

\begin{tabular}{|l|c|c|c|c|}
\hline & \multicolumn{2}{|c|}{ CR234.0 to CR153.0 } & \multicolumn{2}{c|}{ CR153.0 to CR113.0 } \\
\hline & Estimate & s.e. & Estimate & s.e. $^{*}$ \\
\hline Steelhead - All Upstream Releases & 0.9445 & 0.004329 & 0.9906 & 0.002524 \\
\hline
\end{tabular}

\section{Capture Detail:}

\begin{tabular}{|l|c|c|c|c|c|c|}
\hline & \multicolumn{2}{|c|}{ CR153.0 } & \multicolumn{2}{c|}{ CR113.0 } & CR086.2 Survival*Capture \\
\hline & Estimate & s.e.* & Estimate & s.e.* & Estimate & S.e.* \\
\hline Steelhead - All Upstream Releases & 0.7589 & 0.007643 & 0.9280 & 0.004766 & 0.9358 & 0.004556 \\
\hline
\end{tabular}

* Standard error is based on the inverse Hessian.

$\dagger$ Standard error is based on bootstrapping.

Table A.7. Forebay Virtual Release Capture History for Juvenile Steelhead

\begin{tabular}{lcccccccc}
\hline & 111 & 011 & 101 & 001 & 110 & 010 & 100 & 000 \\
\hline Number of Fish & 2088 & 642 & 141 & 73 & 149 & 41 & 36 & 206 \\
\hline
\end{tabular}

Table A.8. Forebay Virtual Release Survival and Capture Detail for Juvenile Steelhead

\section{Survival Detail:}

\begin{tabular}{|l|c|c|c|c|}
\hline & \multicolumn{2}{|c|}{ CR236.0 to CR153.0 } & \multicolumn{2}{c|}{ CR153.0 to CR113.0 } \\
\hline & Estimate & s.e. $\dagger$ & Estimate & s.e.* \\
\hline Steelhead - All Upstream Releases & 0.9442 & 0.004326 & 0.9906 & 0.002525 \\
\hline
\end{tabular}

\section{Capture Detail:}

\begin{tabular}{|l|c|c|c|c|c|c|}
\hline & \multicolumn{2}{|c|}{ CR153.0 } & \multicolumn{2}{c|}{ CR113.0 } & \multicolumn{2}{c|}{ CR086.2 Survival*Capture } \\
\hline & Estimate & s.e.* & Estimate & s.e.* & Estimate & s.e.* \\
\hline Steelhead - All Upstream Releases & 0.7588 & 0.007642 & 0.9273 & 0.004785 & 0.9354 & 0.004567 \\
\hline
\end{tabular}

* Standard error is based on the inverse Hessian.

† Standard error is based on bootstrapping. 


\section{Distribution}

No. of

Copies

\section{External Distribution}

1 Brad Eppard

USACE Portland District

P.O. Box 2946

Portland, OR 97204

1 Mike Langeslay

USACE Portland District

P.O. Box 2946

Portland, OR 97204
No. of

\section{Copies}

\section{Local Distribution}

5 Pacific Northwest National Laboratory TJ Carlson BPO

GE Johnson BPO

GR Ploskey NBON

S Schlahta K6-83

MA Weiland NBON 




\section{iriti}

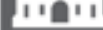

US Army Corps

of Engineers .

Prepared for the U.S. Army Corps of Engineers, Portland District, under a Government Order with the U.S. Department of Energy Contract DE-AC05-76RL01830

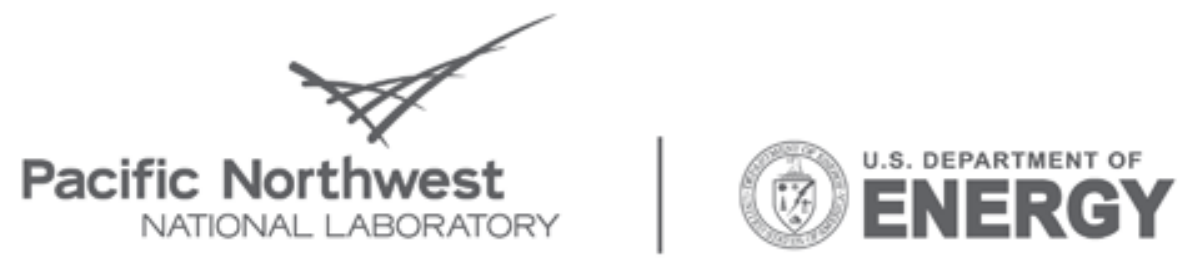

Proudly Operated by Battelle Since 1965

902 Battelle Boulevard

P.O. Box 999

Richland, WA 99352

1-888-375-PNNL (7665)

www.pnl.gov 